\title{
FLORISTIC AND RARE PLANT SURVEY OF THE KOOTENAY PLAINS ECOLOGICAL RESERVE (1996-1997)
}

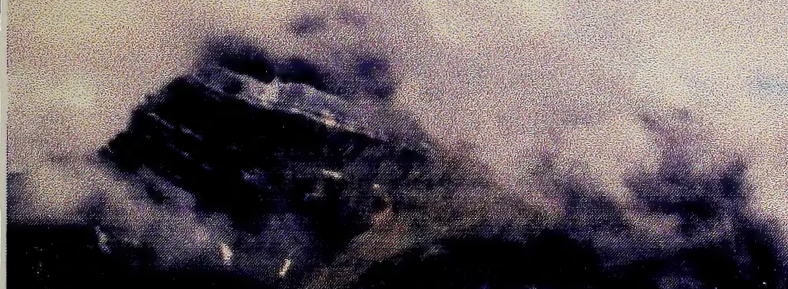

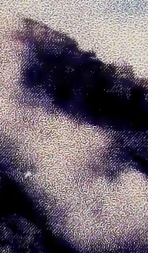

ALBERTA ENURONMENTAL PROTEGTION RESOUREE DATA DIUISION GORPORATE MANAGEMENT SERIIGE

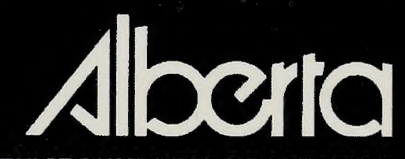

ENVIRONMENTAL PROTECTION

Geographic Dynamics Corp.

10368B - 60 Avenue

Edmonton, Alberta T6H 1G9

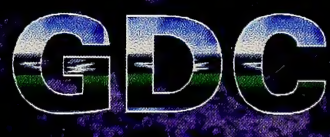

Phone: (403) 436-1217

Fax: (403) 436-4348

E-mail: gdc@planet.eon.net

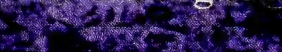

MARCH 1997 



\section{ACKNOWLEDGMENTS}

Staff at Geographic Dynamics Corp. thanks those people who contributed information or resources toward this report. Their assistance is acknowledged.

Verification of plant species for this survey was conducted by several people from the University of Alberta, Biological Sciences Department. Vascular plants were verified by Elaine Gordon, Donna Cherniawsky and Patsy Cotterill. Nonvascular plants were identified by René Belland (mosses \& liverworts) and Bernard Goffinet (lichens).

Several rare plants were made available for photography by Derek Johnson of the Canadian Forest Service, Northern Forestry Centre, and Dr. Randy Bayer and staff of the University of Alberta Herbarium. Their assistance is appreciated.

Staff of Geographic Dynamics Corp. contributed in the following areas: Elaine Gordon, Patsy Cotterill, Greg Greidanus and Craig Halun (field descriptions/data collection); Vincent Futoransky (supervised GPS data collection and summary, site mapping, plant photographs, and report synthesis, editing and production); Tony Szumigalski (report synthesis, editing and production); Darrin Nielsen (plant photographs); Jack Morgan (plant photographs and the graphic design and layout of color-plates); and Andrew Wilson (report figures).

Special thanks to Keith Ainsley, Joyce Gould and John Rintoul of the Resource Data Division, Alberta Environmental Protection for database searches and input into the review process of this report. 



\section{CONTENTS}

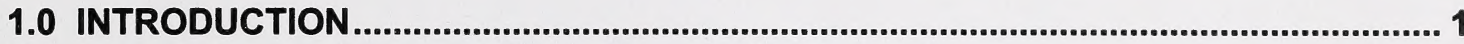

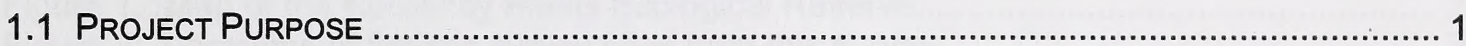

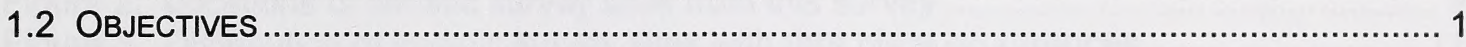

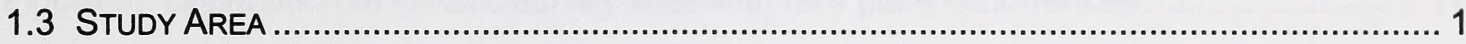

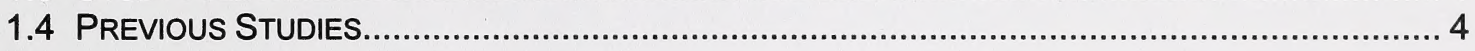

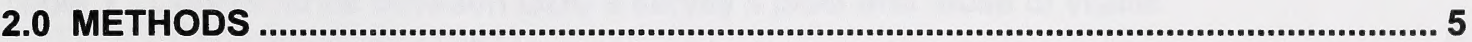

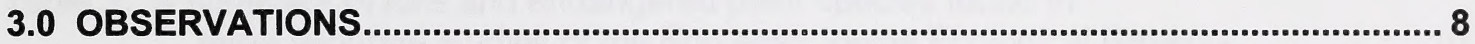

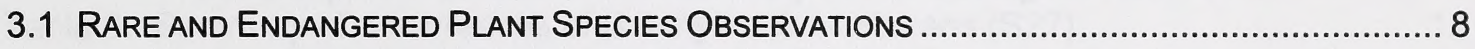

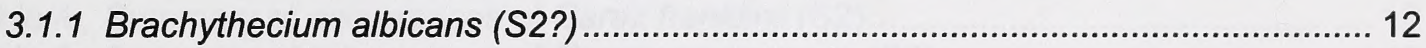

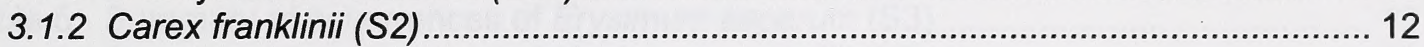

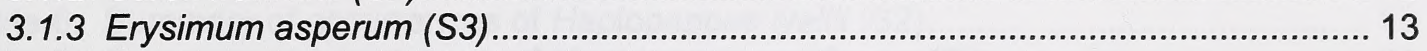

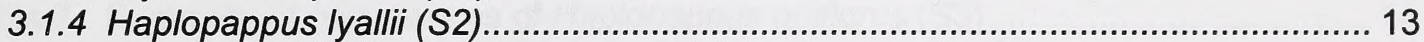

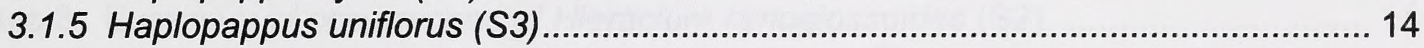

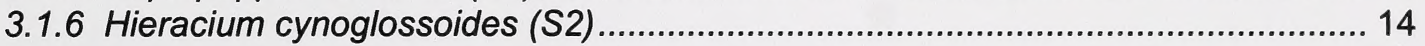

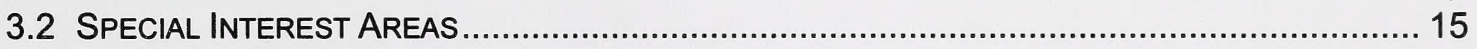

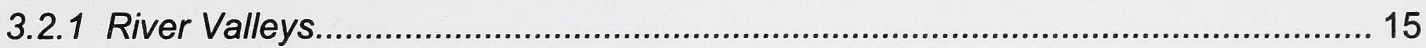

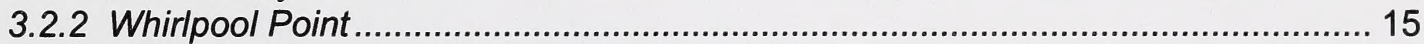

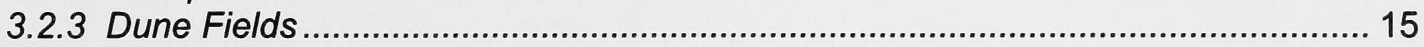

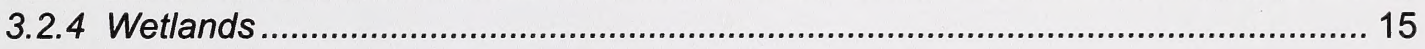

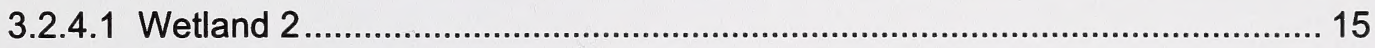

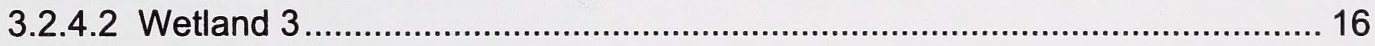

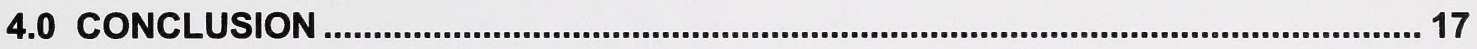

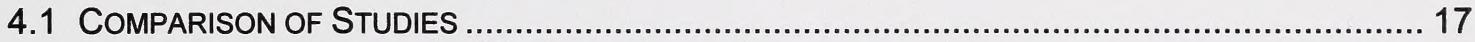

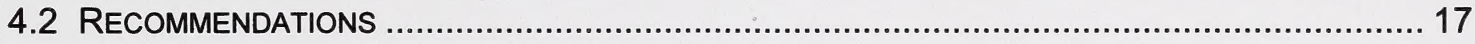

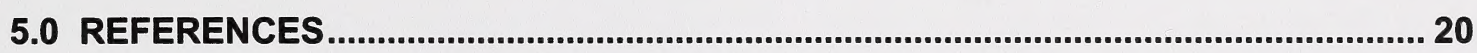

\section{APPENDICES}

1. Distribution of plots over several ecological features and plant community types

2. Rare native plant survey forms

3. Summary statistics for GPS readings at sites with Haplopappus uniflorus (S3)

4. Plot locations for all detailed floristic survey sites

5. Complete plant species list from detailed plot descriptions

6. Habitat and diagnostic features of Brachythecium albicans (S2?)

7. Habitat and diagnostic features of Carex franklinii (S2)

8. Habitat and diagnostic features of Erysimum asperum (S3)

9. Habitat and diagnostic features of Haplopappus lyallii (S2)

10. Habitat and diagnostic features of Haplopappus uniflorus (S3)

11. Habitat and diagnostic features of Hieracium cynoglossoides (S2) 
Figure 1. Map of the Kootenay Plains Ecological Reserve............................................. 2

Figure 2. Locations of floristic survey sites from this survey ......................................... 9

Figure 3. Distribution of floristic survey sites with rare plant occurrences ........................... 11

Table 1. Concordance between GDC's survey's plots and those of Wallis and Wershler (1981) ............................................................................... 5

Table 2. A summary of rare and endangered plant species found in three separate studies of the Kootenay Plains Ecological Reserve.................. 10

Table 3. Summary of occurrences of Brachythecium albicans (S2?).............................. 12

Table 4. Summary of occurrences of Carex franklinii (S2) ............................................ 12

Table 5. Summary of occurrences of Erysimum asperum (S3) .................................... 13

Table 6. Summary of occurrences of Haplopappus lyallii (S2) ................................... 13

Table 7. Summary of occurrences of Haplopappus uniflorus (S3) .................................. 14

Table 8. Summary of occurrences of Hieracium cynoglossoides (S2) ............................. 14 


\subsection{INTRODUCTION}

In 1995, the Kootenay Plains Ecological Reserve was expanded to include areas to the south of Whirlpool Point, to the southwest of the Siffleur Falls area and to the east of the mouth of Abraham Lake. It now encloses a larger number of significant features, such as calcareous cliffs, marshes, fens, dunes and grassland meadows. Due to this expansion, there is a need for an accurate biophysical inventory of these newly added areas. Of particular importance is the need for a survey of vascular and non-vascular plant species that are considered to be rare or endangered.

\subsection{Project Purpose}

The purpose of this project was to:

(1) conduct a floristic survey in order to identify and document the location of rare vascular and non-vascular native plants; describe the site conditions where observed rare plants occur and provide this information for the management of the natural resources of the Kootenay Plains Ecological Reserve; and

(2) to produce a report and a floristic survey site and rare native plant location map for selected, naturally vegetated areas of the Kootenay Plains Ecological Reserve.

\subsection{Objectives}

- To confirm rare native plant species identified in previous rare plant surveys (Kondla 1979, Wallis and Wershler 1981) and to document the characteristics and exact location of the surveyed populations;

- To conduct floristic surveys in landscape positions with the greatest potential for containing rare vascular and non-vascular native plants within the naturally vegetated areas in the Kootenay Plains Ecological Reserve;

- To identify and confirm rare native plant populations from the floristic surveys and document the species exact location on the ground, on maps and on air photos;

- To provide a thematic map depicting the location of all floristic survey sites and all observed rare native plants; and

- To provide a summary report and map according project specifications outlined in the terms of reference.

\subsection{Study Area}

The Kootenay Plains Ecological Reserve is located in the Montane Subregion roughly $50 \mathrm{~km}$ southwest of Nordegg, Alberta along the North Saskatchewan River. Its approximate geographic centre is at $52^{\circ} 03^{\prime} \mathrm{N}$ and $116^{\circ} 25^{\prime} \mathrm{W}$ (Figure 1). Access to the ecological reserve is via the David Thompson Highway (Hwy. 11), while back areas can be reached via various trails on foot or on non-motorized vehicles. The ecological reserve has a range in elevation between 1230 and $1700 \mathrm{~m}$. The approximate elevation for the North Saskatchewan River in this area is $1300 \mathrm{~m}$. 


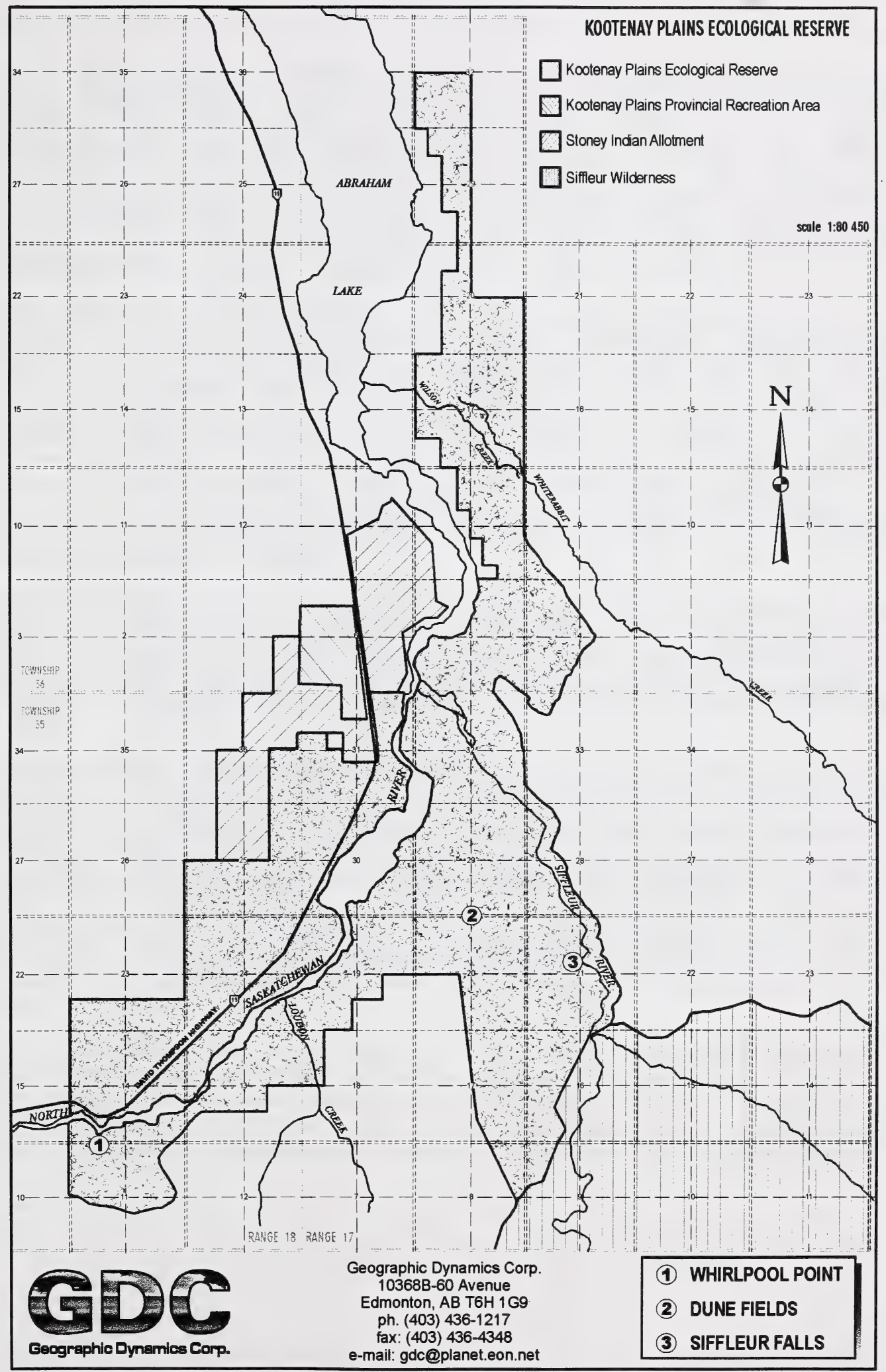

Figure 1. Map of the Kootenay Plains Ecological Reserve. 

The Kootenay Plains Ecological Reserve is in the Montane Subregion (Alberta Environmental Protection 1994b). This region receives an annual range of precipitation from 308 to $1279 \mathrm{~mm}$, with a median value of $515 \mathrm{~mm}$ (Strong 1992). The ecological reserve is in the rainshadow of the surrounding mountains which, when combined with high transpiration rates, results in a drier habitat than surrounding subalpine regions (Bruhjell et al. 1996). Mean summer temperatures for this region are from 10 to $11^{\circ} \mathrm{C}$, Mean winter temperatures are greater than other montane ecoregions in Alberta (Bruhjell et al. 1996). Chinook activity reduces the influence of the incoming arctic air, and raises the winter temperatures (Strong 1992). Freezing temperatures can occur in any month, but are infrequent in July.

Brunisolic soils are dominant in the area. Luvisolic, Gleysolic, and Organic soils are rare or have not been completely sampled (Bruhjell et al. 1996). The grassland soils in the area are strongly calcareous with dark brown to black surface horizons, typically well drained, and have a poorly developed organic mineral association (Wallis and Wershler 1981). Soils belonging to the Regosolic Order are common and have been described as young, and generally lacking well developed profiles probably due to factors like instability of the material, the nature of the material and the cold, dry environment (Bruhjell et al. 1996). The soils in the river valley are dominated by a complex system of alluvial fans and active floodplains (Bruhjell et al. 1996). These riparian areas are often the site of rare plants, and are significant to the study. Surficial deposits of silty eolian material (loess) are common in the ecological reserve (Wallis and Wershler 1981, Bruhjell et al. 1996).

Grasslands and other drought tolerant communities are dominant in the Montane Subregon relative to the forests because of generally higher evapotranspiration created by Chinooks and a rain-shadow (Bruhjell et al. 1996). This grassland dominance was perpetuated by both the active fire history of the area, and the overgrazing by both wild and domestic ungulates. These factors began to be restricted by the establishment of the ecological reserve in 1979 (Bruhjell et al. 1996).

The Kootenay Plains Ecological Reserve is host to a wide array of plant life. This region is vegetatively distinct because of the presence of Pinus flexilis (Strong 1992). The ecological reserve also contains lodgepole pine (Pinus contorta) forests in the uplands, and white spruce (Picea glauca) forests on fluvial terraces and along watercourses. Deciduous forests are less widespread than the coniferous forests, and are localized in the ecological reserve (Wallis and Wershler 1981). Grassland plant communities typically have Agropyron dasystachyum, Koeleria macrantha, and various species of forbs as important components (Bruhjell et al. 1996). Additional herbaceous plant communities have been previously found in the riparian and lowland areas associated with the North Saskatchewan river edge (Kondla 1979; Wallis and Wershler 1981).

Both the North Saskatchewan and Siffleur rivers run through the Kootenay Plains Ecological Reserve. Other large water bodies include the Louden, White Rabbit and Wilson creeks. Large marshes and fens can be found southeast of Whirlpool Point and southwest of Siffleur Falls (Figure 1). Because of the presence of these water bodies, there is a high diversity of riparian and wetland plant communities, resulting in a releatively high species richness in the area. 


\subsection{Previous Studies}

An initial vegetation inventory of the Kootenay Plains was carried out in 1978 and 1979 by Kondla (1979) who found several areas with a high diversity of rare and endangered plants. In 1979 and 1981, Wallis and Wershler (1981) sampled a number of sites within and near the Kootenay Plains Ecological Reserve. They used two methods in their investigation. At certain sites, they recorded plant species cover estimates and a presence-absence list (sample sites) while at other sites they compiled a presence-absence list only (collection sites).

Wallis and Wershler (1981), did not find either the diversity of species or the abundance of individuals reported by Kondla (1979) in his earlier study. For example, Kondla (1979) reported abundant Primula mistassinica on the calcareous flats of the North Saskatchewan River; however, he may have found $P$. mistassinica only in areas north of the ecological reserve. Although Wallis and Wershler did locate $P$. mistassinica, the populations were small and relatively few. They attributed the differences to a very late spring in 1981.

Bruhjell et al. (1996) conducted a biophysical inventory of the Kootenay Plains Ecological Reserve in 1995, with an emphasis on significant ecological features. Bruhjell et al. (1996) found relatively few rare plant species and attributed this to species phenology, climatic factors, and low sampling intensity. 


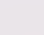




\subsection{METHODS}

Plots were chosen in one of two ways. The first method was to revisit the plots that Wallis and Wershler (1981) established in order to relocate potential rare and endangered plants found in the earlier study. Because permanent plot markers were not established after the 1981 study, the revisited plots were approximated from both old site descriptions and rough positions delineated on their report map. Generally, the new survey plots were within 100 metres of the plots from the previous study. A comparison of the plots between this survey and the one performed by Wallis and Wershler (1981) is provided below (Table 1). Also, additional areas which had been sampled by Wallis and Wershler (1981) were investigated but were not sampled in this study because the plant communities present were already included in a number of representative plots, or there were no rare or endangered plants present.

Table 1. Concordance between this GDC's plots and those of Wallis and Wershler (1981)

\begin{tabular}{ll}
\hline \multicolumn{1}{c}{ GDC } \\
$(1996)$ & W\&W (1981) \\
\hline 01 & oc 16 \\
${ }^{*} 02$ & cc $24-28$, oc23 \\
03 & t J \\
09 & cc $4-5$ \\
$* 10$ & cc 10 \\
11 & cc 9 \\
$* 12$ & cc 25, oc 23 \\
16 & cc $11-13$, oc 15 \\
$* 17$ & cc $11-13$, oc 15 \\
18 & cc $11-13$, oc 15 \\
19 & cc $11-13$, oc 15 \\
23 & cc 14 \\
24 & cc $33-34$ \\
26 & cc 36 \\
27 & cc $17-19$, oc 1 \\
29 & oc 2 \\
30 & cc 19, oc 1 \\
33 & t M \\
34 & t M \\
$* 35$ & oc 9 \\
$* 37$ & oc 9 \\
$* 40$ & t I \\
42 & oc 20 \\
47 & t C \\
48 & cc 20 \\
$* 51$ & t H \\
$* 52$ & t F \\
\hline
\end{tabular}

* plots with rare and endangered plant(s) in this survey

cc closed circle; plot numbers; July 28-Aug 2, 1981

oc open circle; collection sites; July 28-Aug 2, 1981

t triangle; collection sites; June 8, 1981

The second method of site selection was to investigate significant ecological features as defined by Wallis and Wershler (1981). This was done because of the increased likelihood of finding rare or endangered plant species in these areas. Wallis and Wershler (1981) 

selectively sampled significant ecological features such as calcareous rock outcrops, wetlands, grasslands (which showed diversity or richness apparent in certain color patterns evident on the false color aerial photographs), and river channel edges. Examples of significant ecological features from the current study include the fen located southwest of the Siffleur Falls area, and the calcareous cliffs south of Whirlpool Point.

In this survey, a total of 54 plots were sampled. One-half of these plots were established in the same or approximate location as the plots of Wallis and Wershler (1981), while half consisted of new sites encompassing a variety of habitat types (Appendix 1). While most sites were located in grasslands, wetlands, seepage areas, and riparian habitats, some were placed in forested areas as well. It should be noted that some plots were sampled outside of current ecological reserve boundaries in attempt to match Wallis and Wershler's sites.

A description of each site was recorded following the guidelines described in the Ecological Land Survey Site Description Manual (Alberta Environmental Protection 1994a). Both site description (LISD 15B (Rev. 3/93)) and vegetation (LISD 14B (Rev. 3/93)) forms were used for the field plots. Site forms were completed with the exception of the fields designated for aerial photography, regeneration, soil drainage, perviousness, ecological moisture regime and nutrient regime. Vegetation forms were filled out completely.

At each site a rectangular $100 \mathrm{~m}^{2}$ plot was established and plant relative abundance was recorded by visual estimates of the percent of ground covered by each species. Typically the vegetation plot dimensions measured 10 by $10 \mathrm{~m}$. However, in order to maintain specific community sampling, plots located in narrow areas (i.e. along river margins) were measured in 20 by $5 \mathrm{~m}$ plots. All strata of vegetation present were recorded within the vegetation plot as per the methods outlined by Alberta Environmental Protection (1994a). Data collected on the native species were restricted to their presence in the plots, but significant plant species that were found outside of the plot were also noted. Plants were either keyed out in the field or brought back to the office for identification. The final authority for the taxonomy of vascular plants was Flora of Alberta (Moss 1983). The following checklists were used to assess whether a plant was rare or endangered:

- A checklist of the rare vascular plants of Alberta (Packer and Bradley 1984);

- Provincial tracking list of vascular plant species of concern in Alberta (Alberta Parks 1996); and

- Alberta natural heritage information centre tracking list: mosses of special concern (Alberta Parks 1995).

The latter two lists were updated and revised in November 1996. As a result, four plant species found in this survey (Carex franklinii, Erysimum asperum, Haplopappus lyallii, and Hieracium cynoglossoides) were added to the updated list that were not known to be species of concern during the course of field sampling. These plants are included in this report as rare plant observations, however, some data are incomplete and will need to be collected in the spring of 1997.

Photographs were taken of site and ground cover for all plots. If a known rare or endangered plant population was found, an associated rare native plant survey form was completed (Appendix 2). The site in which the plant population was found was also clearly marked for later relocation. A piece of rebar $(75 \mathrm{~cm}$ length) was placed within $10 \mathrm{~m}$ of the population, and capped with a surveyor's cap. This cap had the element code for the rare plant species tooled into it using a steel die. An aluminum marker, with the same code for the rare plant tooled into 

it, was placed on a witness feature within $100 \mathrm{~m}$ of the population. Bearing and distance were recorded on the rare native plant survey forms. This witness feature was either a tree or an additional piece of rebar. Witness features were selected in highly visible areas (from trails or roads) marked with horizontal bars of yellow and blue tree paint. All the pieces of rebar used to mark plots were sprayed with corresponding yellow spray paint. Paths to sites which had rare or endangered plant species that were not easily located along a trail were flagged with day-glo orange flagging tape.

Witness features for plots with known rare and endangered plants were located using a global positioning system (GPS). The GeoExplorer GPS receiver by Thimble was selected since its specifications of accuracy fell within acceptable limits for this project (i.e. witness features located within 30 metres). At least 40 positions were attempted and recorded for each plot. These positions were then output into ASCII format from PFINDER software and summary statistics were calculated using SAS software (Appendix 3). A mean position was then recorded for each of these plots.

All plots were located on 1:50,000 scale resource access maps (Alberta Environmental Protection 1994c,d) from aerial photographs. Plot locations were pin pricked and marked in black ink on both sides of 1:15 000 and 1:20 000 scale aerial photographs. If a rare or endangered plant species occurred on that plot, the rare plant element code was also marked on the aerial photograph in green ink on both sides.

In addition, an area outside of the current Kootenay Plains Ecological Reserve near White Goat Lake described by Kondla (1979) was informally investigated for the presence of rare and endangered species. Detailed data forms were not completed since this site was located outside of the immediate study area.

7 



\subsection{OBSERVATIONS}

Sites were selected throughout the Kootenay Plains Ecological Reserve across several ecological features and plant community types (Appendix 1). Most plots were located in the valley floor macro-position with a level meso-position and straight site surface shape. The successional status was most often pioneer or young seral. Physiognomy varied from open grasslands to forested stands. Several areas are notable for distinctive plants and abundance of species; however, the riparian mud flats of the North Saskatchewan River valley support the greatest richness of species of all the areas sampled. Locations of the floristic survey sites for this study are plotted (Figure 2) and listed according to latitude, longitude, and legal land description (Appendix 4). A complete list of all vascular and non-vascular species found in the study are located in Appendix 5. Color photo-plates are provided in Appendixes 6 through 11 to further illustrate the habitat and diagnostic features of all rare plants observed.

\subsection{Rare and Endangered Plant Species Observations}

A total of 8 rare and endangered plant species were found in this study (Table 2); however, two of these (Primula mistassinica and Salix lanata var. calcicola) were reported outside of the immediate study area. Five of the rare and endangered plant species (Brachythecium albicans, Erysimum asperum, Haplopappus Iyallii, Hieracium cynoglossoides, and S. lanata var. calcicola) found in this study were not recorded by either Kondla (1979), Wallis and Wershler (1981), or Bruhjell et al. 1996). However, the first species (B. albicans) is a moss (non-vascular) species, which is of a growth form that was not the focus in any of the previous studies. Rare Native Plant Survey Forms (Appendix 2) were only completed for populations of Haplopappus uniflorus (S3) in our survey during the summer of 1996. Rare Native Plant Survey Forms were not completed for Brachythecium albicans (S2?), since it was not identified until after the field season, and Carex franklinii (S2), Erysimum asperum (S3), Haplopappus lyallii (S2), and Hieracium cynoglossoides (S2) were not added to the provincial tracking list until November 1996.

Four species of concern (Hippuris montana, Ledum glandulosum, Pellaea glabella, and Senecio cymbalarioides) reported by both Kondla (1979) and Wallis and Wershler (1981) were not located in this study. Wallis and Wershler (1981) also reported four potential species of concern (Botrychium dusenii, Carex rostrata, Castilleja pallida, and Salix alaxensis) that were not recorded by Kondla (1979) or in this study. However, it is uncertain whether the varieties of $C$. rostrata and $S$. alaxensis identified in Wallis and Wershler's study were the actual varieties ranked as $\mathrm{S} 2$ in the Alberta provincial tracking list. Haplopappus uniflorus and Primula mistassinica were the only known rare and endangered species confirmed in all three studies.

The rare and endangered plant species' populations had low cover values (<1\%) in all plots; however, the plots were fairly well distributed across the study area (Figure 3 ). The occurrences and habitats of each rare or endangered species encountered in this study are documented in the following subsections. 


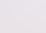




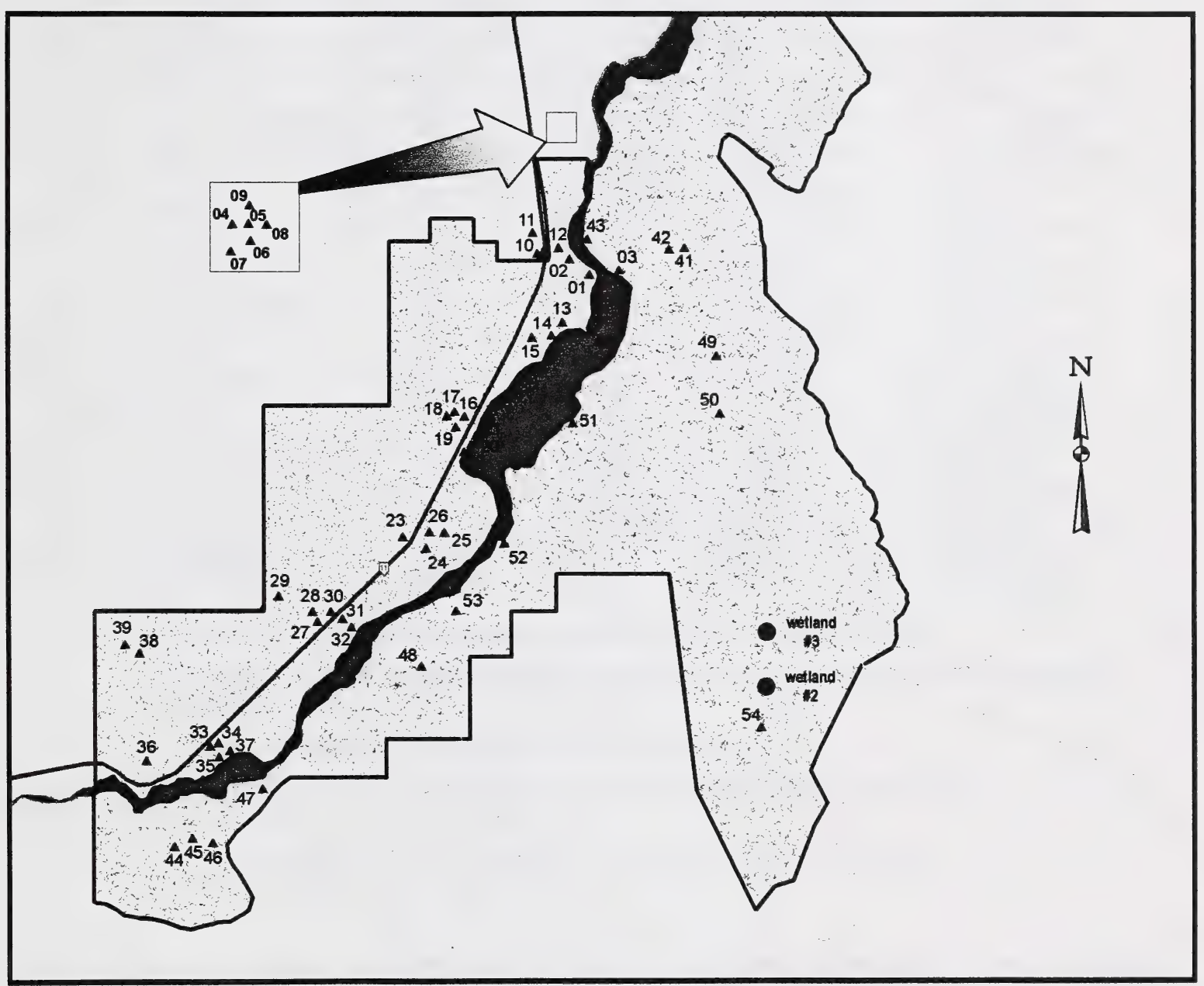

scole 1:67042
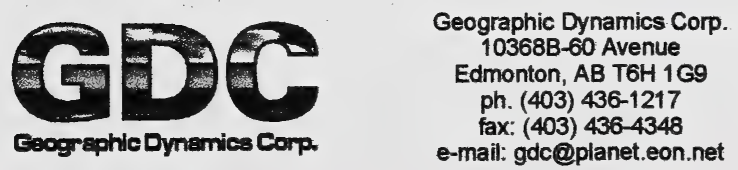

- David Thompson Highway (11)

Kootenay Plains

Ecological Reserve

North Saskatchewan River

- Floristic Survey Sites

Wetlands-informal descriptions

Figure 2. Location of floristic survey sites and wetlands. 
Table 2. A summary of rare and endangered plant species found in three separate studies of the Kootenay Plains Ecological Reserve

\begin{tabular}{|c|c|c|c|c|}
\hline Species & Rank & $\begin{array}{c}\text { Kondla } \\
(1979) \\
\end{array}$ & $\begin{array}{c}\text { Wallis and } \\
\text { Wershler (1981) }\end{array}$ & $\begin{array}{c}\text { This Survey } \\
(1996)\end{array}$ \\
\hline Botrychium dusenii & SU & not reported & reported & not reported \\
\hline Brachythecium albicans $^{\top}$ & S2? & N/A & N/A & reported \\
\hline Carex franklinii ${ }^{2}$ & S2 & not reported & reported & reported \\
\hline Carex rostrata var. sensu strictu & S2 & not reported & reported $^{5 ?}$ & not reported \\
\hline Castilleja pallida & SR & not reported & reported & not reported \\
\hline Erysimum asperum ${ }^{2}$ & S3 & not reported & not reported & reported \\
\hline Haplopappus lyallii ${ }^{2}$ & S2 & not reported & not reported & reported \\
\hline Haplopappus uniflorus ${ }^{3}$ & S3 & reported & reported & reported \\
\hline Hieracium cynoglossoides ${ }^{2}$ & S2 & not reported & not reported & reported \\
\hline Hippuris montana ${ }^{3}$ & $\mathrm{~S} 2$ & reported & reported & not reported \\
\hline Ledum glandulosum ${ }^{3}$ & S3? & reported & reported & not reported \\
\hline Pellaea glabella & $\mathrm{S2}$ & reported & reported & not reported \\
\hline Primula mistassinica & S2 & reported & reported & reported $^{4}$ \\
\hline Salix alaxensis ${ }^{3}$ var. alaxensis & S2 & not reported & reported $^{5 ?}$ & not reported \\
\hline Salix lanata var. calcicola ${ }^{3}$ & S1 & not reported & not reported & reported $^{4}$ \\
\hline Senecio cymbalarioides $^{3}$ & S1 & reported & reported & not reported \\
\hline
\end{tabular}

I Non-vascular species, which were not surveyed for (N/A) in the first two studies.

2 Species on the newly updated provincial checklist (Nov. 1996) which was not available at the time of survey.

3 Species also considered rare by Packer and Bradley (1984).

$4 \quad$ Reported outside of the immediate study area, therefore, a detailed rare and endangered plant survey form was not completed.

5? Species reported by Wallis and Wershler (1981); however, they did not identify specimen to variety, thus, status is uncertain.

Rank is based on the Alberta Natural Heritage Information Centre tracking list updated November 1996 (S1critically imperiled; S2-imperiled; S3-rare-uncommon; SR-reported for Alberta but lacking sufficient documentation; SU-status uncertain). 


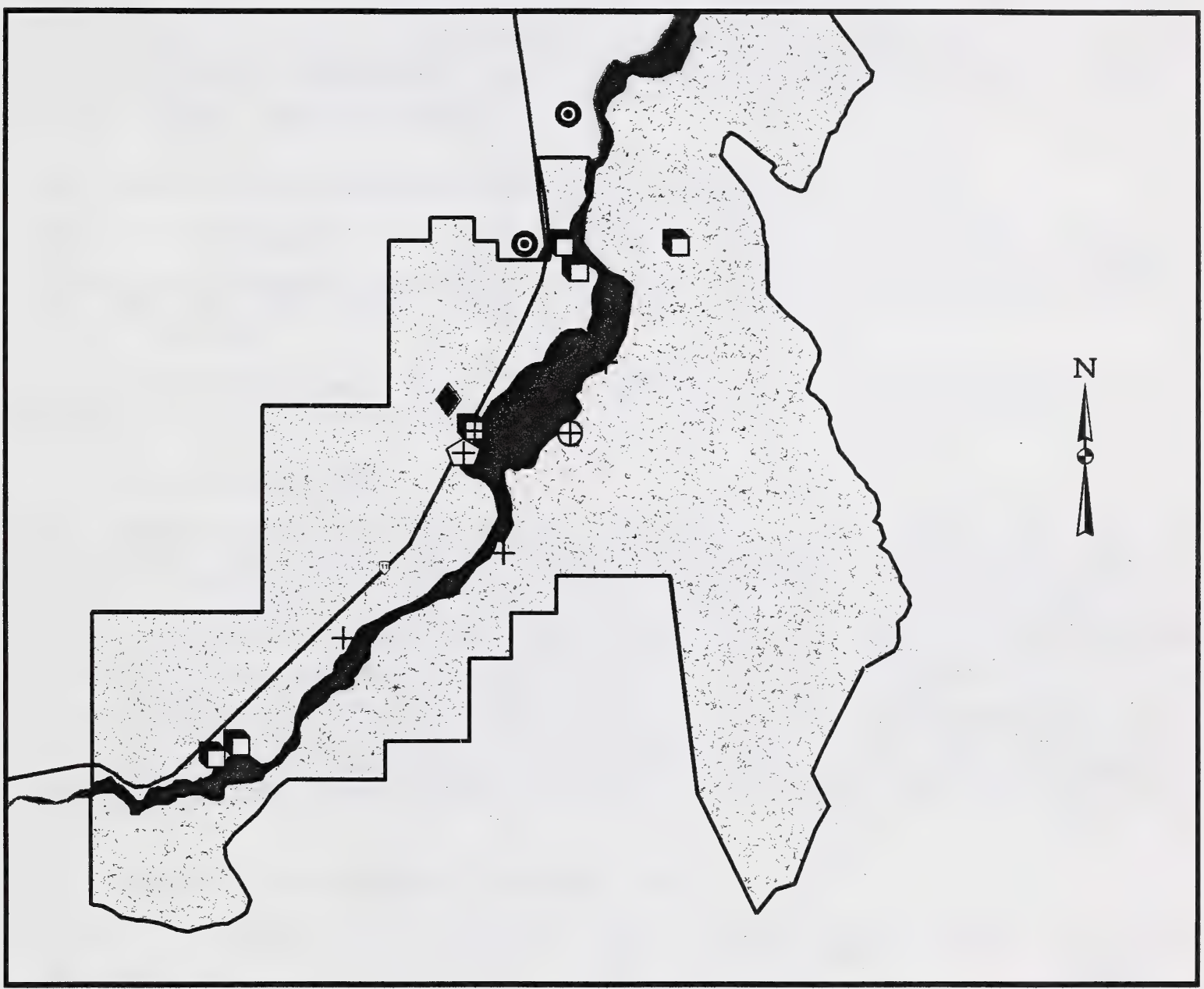

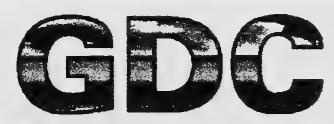

Eeographle Dynamics Corp.

Geographic Dynamics Corp. 10368B-60 Avenue Edmonton, $A B$ T6H $1 G 9$ ph. (403) 436-1217 fax: (403) 436-4348 e-mail: gdc@planet.eon.net scale 1:67042

Brachythecium albicans (S2?)

+ Carex franklinii (S2)

- Erysimum asperum (S3)

$\checkmark$ Haplopappus lyallii (S2)

- Haplopappus uniflorus (S3)

Hieracium cynoglossoides (S2)
— David Thompson Highway (11)

Kootenay Plains

Ecological Reserve

North Saskatchewan River

Figure 3. Location of floristic survey sites with rare plant occurrences. 


\subsubsection{Brachythecium albicans (S2?)}

Brachythecium albicans was the only non-vascular species of concern identified in this survey. This species was found with low cover in one plot (51) located on the east shore of the North Saskatchewan River (Table 3, Figure 3). The associated riparian plant community had a welldeveloped low shrub layer dominated by Salix brachycarpa, Potentilla fruticosa, and Betula glandulosa, but a very sparse tree layer of Picea glauca. The site was fairly rich in forb species, with several species indicative of a high pH conditions (e.g., Tofielda glutinosa, Pedicularis groenlandica, and Triglochin palustris).

Table 3. Summary of occurrences of Brachythecium albicans(s2?)

\begin{tabular}{cccccccc}
\hline $\begin{array}{c}\text { Plot } \\
\#\end{array}$ & Location & $\begin{array}{c}\text { Elevation } \\
(\mathrm{ft})\end{array}$ & Habitat & $\begin{array}{c}\text { Plot Size } \\
\text { (ha) }\end{array}$ & Cover & Vigor & $\begin{array}{c}\text { \# of } \\
\text { individuals }\end{array}$ \\
\hline \hline 51 & $52^{\circ} 02^{\prime} 06^{\prime \prime} \mathrm{N} 116^{\circ} 24^{\prime} 31^{\prime \prime} \mathrm{W}$ & 4300 & River flat & 0.01 & $<1 \%$ & $*$ & \\
\hline
\end{tabular}

* needs to be determined

Ireland (1982) indicated that $B$. albicans ranges from Greenland to Alaska and may be found on grassy ground and on the trunks of trees.

\subsubsection{Carex franklinii (S2)}

Carex franklinii was one of the most frequently encountered rare and endangered plant species in the sampled floristic survey sites. This sedge was recorded in six different plots (Table 4) along or near the edge of the North Saskatchewan River (Figure 3). All of these plots were located in level sites with straight site surface shapes and were at a pioneer or young seral stage. This species was associated with riparian plant communities possessing a low shrub layer dominated by Betula glandulosa, Potentilla fruticosa, or Salix spp., and sometimes with a tree stratum of Picea glauca. These communities tended to be rich in herb species but with low cover values. Both forbs and graminoids were present, but no single species seemed to dominate the herb stratum. A large number of these species were calciophiles, indicating a highly calacareous environment. Similarly, Wallis and Wershler (1981) found C. franklinii on calcareous alluvial terraces.

Table 4. Summary of occurrences of Carex franklinii (s2)

\begin{tabular}{|c|c|c|c|c|c|c|c|}
\hline $\begin{array}{l}\text { Plot } \\
\#\end{array}$ & Location & $\begin{array}{c}\text { Elevation } \\
\text { (ft) }\end{array}$ & Habitat & $\begin{array}{c}\text { Plot Size } \\
\text { (ha) }\end{array}$ & Cover & Vigor & $\begin{array}{c}\text { \# of } \\
\text { individuals }\end{array}$ \\
\hline 20 & $52^{\circ} 01^{\prime} 54^{\prime \prime} \mathrm{N} 116^{\circ} 25^{\prime} 29^{\prime \prime} \mathrm{W}$ & 4400 & Floodplain & 0.01 & $<1 \%$ & * & * \\
\hline 21 & $52^{\circ} 01^{\prime} 56^{\prime \prime} \mathrm{N} 116^{\circ} 25^{\prime} 26^{\prime \prime} \mathrm{W}$ & 4400 & River edge & 0.01 & $<1 \%$ & $*$ & $*$ \\
\hline 32 & $52^{\circ} 00^{\prime} 58^{\prime \prime} \mathrm{N} 116^{\circ} 26^{\prime} 23^{\prime \prime} \mathrm{W}$ & 4400 & River edge & 0.01 & $<1 \%$ & * & * \\
\hline 40 & $52^{\circ} 02^{\prime} 29^{\prime \prime} \mathrm{N} 116^{\circ} 24^{\prime} 08^{\prime \prime} \mathrm{W}$ & 4400 & River flat & 0.01 & $<1 \%$ & fair (2) & * \\
\hline 51 & $52^{\circ} 02^{\prime} 06^{\prime \prime} \mathrm{N} 116^{\circ} 24^{\prime} 31^{\prime \prime} \mathrm{W}$ & 4300 & River flat & 0.01 & $<1 \%$ & $\operatorname{good}(3)$ & * \\
\hline 52 & $52^{\circ} 02^{\prime} 29^{\prime \prime} \mathrm{N} 116^{\circ} 25^{\prime} 08^{\prime \prime} \mathrm{W}$ & 4300 & Mud flat & 0.01 & $<1 \%$ & $\operatorname{good}(3)$ & $*$ \\
\hline
\end{tabular}

* needs to be determined

Generally, C. franklinii can be found in dry to moist open areas up to alpine elevations and seems to be confined in the province to west-central Alberta within the Rocky Mountain Natural Region (Moss 1983). 



\subsubsection{Erysimum asperum (S3)}

Erysimum asperum is a member of the mustard family (Cruciferae). This species was found in two floristic survey sites (08 and 10) located just outside of the Kootenay Plains Ecological Reserve Boundary (Table 5, Figure 3). These sites may represent a north-western range extension of $E$. asperum in Alberta when their location is compared with the distribution maps of Moss (1983). Both of these plots were on Stoney Indian Allotment land situated to the west of the Ecological Reserve near areas that were previously surveyed by Wallis and Wershler (1981). Both occurrences of this species were in fairly dry, open areas with a pioneer seral successional status. Plot 08 was located in a level topographic position with a straight site surface shape, while plot 10 was located in an upper slope position with a convex site surface shape, a gentle slope (6\%), and a southerly aspect. Plot 08 was in an Agropyron dasystachyum-Koeleria macrantha grassland community while plot 10 was in a Juniperus horizontalis-Arctostaphylos uva-ursilAntennaria parviflora/lichen community in association with an open Picea glauca forest.

Table 5. Summary of occurrences of Erysimum asperum (s3)

\begin{tabular}{cccccccc}
\hline $\begin{array}{c}\text { Plot } \\
\#\end{array}$ & Location & $\begin{array}{c}\text { Elevation } \\
(\mathrm{ft})\end{array}$ & Habitat & $\begin{array}{c}\text { Plot Size } \\
\text { (ha) }\end{array}$ & Cover & Vigor & $\begin{array}{c}\text { \# of } \\
\text { individuals }\end{array}$ \\
\hline \hline 08 & $52^{\circ} 03^{\prime} 41^{\prime \prime} \mathrm{N} 116^{\circ} 24^{\prime} 31^{\prime \prime} \mathrm{W}$ & 4400 & Meadow & 0.01 & $<1 \%$ & fair (2) & $*$ \\
10 & $52^{\circ} 03^{\prime} 02^{\prime \prime} \mathrm{N} 116^{\circ} 24^{\prime} 50^{\prime \prime} \mathrm{W}$ & 4400 & $\begin{array}{c}\text { Open canopy } \\
\text { forest }\end{array}$ & 0.01 & $<1 \%$ & dead (0) & $*$ \\
\hline
\end{tabular}

* needs to be determined

Moss (1983) states that $E$. asperum occurs on dry sandy prairies form southern British Columbia to Minnesota while Looman and Best (1979) suggest that it is common in the prairies but rare in the parklands.

\subsubsection{Haplopappus lyallii (S2)}

One of two rare species from the genus Haplopappus identified in this survey, $H$. lyallii was only found at one site (Table 6). This plant was located on a floodplain at the west side of the North Saskatchewan River in a level topographic position (Figure 3). The riparian plant community had a sparse low shrub layer of Potentilla fruticosa, Betula glandulosa, Salix glauca, and Arctostaphylos uva-ursi. There were several herbaceous species present; however, all had low cover values. The sparse graminoid stratum was dominated by several species of Carex $(C$. franklinii, C. gynocrates, C. aquatilis, and C. deweyana) and Agropyron (A. violaceum, $A$. dasystachyum, and A. trachycaulum).

Table 6. Summary of occurrences of Haplopappus lyallii (s2)

\begin{tabular}{cccccccc}
\hline $\begin{array}{c}\text { Plot } \\
\#\end{array}$ & Location & $\begin{array}{c}\text { Elevation } \\
(\mathrm{ft})\end{array}$ & Habitat & $\begin{array}{c}\text { Plot Size } \\
\text { (ha) }\end{array}$ & Cover & Vigor $\begin{array}{c}\text { \# of } \\
\text { individuals }\end{array}$ \\
\hline \hline 20 & $52^{\circ}$ 01' $54^{\prime \prime} \mathrm{N} 116^{\circ} 25^{\prime} 29^{\prime \prime} \mathrm{W}$ & 4400 & Floodplain & 0.01 & $<1 \%$ & $*$ & $*$ \\
\hline
\end{tabular}

* needs to be determined

This record of $H$. lyallii from the montane represents a different habitat type than the typical one according to Looman and Best (1979) and Moss (1983). Both of these studies state that this species is typically found on dry alpine slopes and ridges in the southern rocky mountains. This record should be investigated as a possible northern range extension of $H$. lyallii in Alberta. 



\subsubsection{Haplopappus uniflorus (S3)}

Haplopappus uniflorus was one of the most frequently found species of concern in this study and was identified in six plots (Table 7). This was the only species for which detailed Rare Native Plant Survey Forms were completed during the 1996 field season. $H$. uniflorus was most commonly found along the riparian mud flats of the North Saskatchewan River valley, but was also encountered in similar habitat along the Siffleur River (Figure 3). All plots in which this species was found were located in level areas with a straight site surface shape. The successional staus of the associated riparian plant communities ranged from pioneer seral to mature seral. The physionomy varied from open grasslands and shrub lands to open Picea glauca stands. Dominant graminoids were commonly Agropyron dasystachyum and Carex spp., while Juniperus horizontalis and Pontentilla fruticosa were common shrubs associated with Haplopappus uniflorus.

Table 7. Summary of occurrences of Haplopappus uniflorus(s3)

\begin{tabular}{cccccccc}
\hline $\begin{array}{c}\text { Plot } \\
\#\end{array}$ & Location & $\begin{array}{c}\text { Elevation } \\
\text { (ft) }\end{array}$ & Habitat & $\begin{array}{c}\text { Plot Size } \\
\text { (ha) }\end{array}$ & Cover & Vigor & $\begin{array}{c}\text { \# of } \\
\text { individuals }\end{array}$ \\
\hline \hline 02 & $52^{\circ} 02^{\prime} 54^{\prime \prime} \mathrm{N} 116^{\circ} 24^{\prime} 33^{\prime \prime} \mathrm{W}$ & 4400 & Meadow & 0.01 & $<1 \%$ & fair (2) & 12 \\
12 & $52^{\circ} 02^{\prime} 58^{\prime \prime} \mathrm{N} 116^{\circ} 24^{\prime} 36^{\prime \prime} \mathrm{W}$ & 4400 & Meadow & 0.01 & $<1 \%$ & fair (2) & 3 \\
21 & $52^{\circ} 01^{\prime} 56^{\prime \prime} \mathrm{N} 116^{\circ} 25^{\prime} 26^{\prime \prime} \mathrm{W}$ & 4400 & River edge & 0.01 & $<1 \%$ & fair (2) & 2 \\
35 & $52^{\circ} 00^{\prime} 20^{\prime \prime} \mathrm{N} 116^{\circ} 27^{\prime} 29^{\prime \prime} \mathrm{W}$ & 4400 & River edge & 0.01 & $<1 \%$ & fair (2) & 6 \\
37 & $5^{\circ} 00^{\prime} 20^{\prime \prime} \mathrm{N} 116^{\circ} 27^{\prime} 21^{\prime \prime} \mathrm{W}$ & 4300 & Meadow & 0.01 & $<1 \%$ & fair (2) & 8 \\
41 & $52^{\circ} 02^{\prime} 57^{\prime \prime} \mathrm{N} 116^{\circ} 23^{\prime} 28^{\prime \prime} \mathrm{W}$ & 4400 & River edge & 0.01 & $<1 \%$ & fair (2) & 3 \\
\hline
\end{tabular}

Wallis and Wershler (1981) found $H$. uniflorus to be locally abundant in the Whirlpool Point area in open woodland, fen margins, and meadows. In Alberta, this species is most commonly found on dry to moist open slopes, banks and roadsides, and seems to be confined to the west-central part of the province (Moss 1983).

\subsubsection{Hieracium cynoglossoides (S2)}

Hieracium cynoglossoides, like the previous two species, is a member of the Compositae or sunflower family. This species was only found in one plot (Table 8, Figure 3) during the course of this study. Situated west of Hwy. 11 in a lower slope topographic position, plot 17 was at the highest elevation (4500 ft.) of all plots containing rare or endangered species in this study. $H$. cynoglossoides was found in an area with a strong slope, concave site surface shape, and a young seral successional status. The plant community was dominated by low shrubs (Arctostaphylos uva-ursi and Juniperus horizontalis) but a sparse tall shrub layer of Pinus contorta and Picea glauca was also present.

Table 8. Summary of occurrences of Hieracium cynoglossoides (s2)

\begin{tabular}{|c|c|c|c|c|c|c|c|}
\hline $\begin{array}{l}\text { Plot } \\
\text { \# }\end{array}$ & Location & $\begin{array}{l}\text { Elevation } \\
\text { (ft) }\end{array}$ & Habitat & $\begin{array}{l}\text { Plot Size } \\
\text { (ha) }\end{array}$ & Cover & Vigor & $\begin{array}{c}\text { \# of } \\
\text { individuals }\end{array}$ \\
\hline 17 & $52^{\circ} 02^{\prime} 06^{\prime \prime} \mathrm{N} 116^{\circ} 25^{\prime} 34^{\prime \prime} \mathrm{W}$ & 4500 & $\begin{array}{c}\text { Open canopy } \\
\text { forest }\end{array}$ & 0.01 & $<1 \%$ & 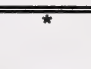 & \\
\hline
\end{tabular}

* needs to be determined

In Alberta, $H$. cynoglossoides is generally distributed in the southern rocky mountains and Cypress Hills in open woods and montane slopes (Moss 1983). This report of the species should be further investigated as a possible northern range extension. 



\subsection{Special Interest Areas}

Several areas of ecological interest and significance were noted during this study and are briefly described below.

\subsubsection{River Valleys}

The riparian mud flats of the North Saskatchewan River valley support the highest richness of species of all the areas sampled. They contain an abundance of sedges and several orchid species, primarily on the edge of the mud flats among the willows. Haplopappus uniflorus was abundant in these areas and along hiking trails. These riparian zones are also where Brachythecium albicans, Carex franklinii, Primula mistassinica, and Salix lanata var. calcicola may be found. Pinguicula vulgaris was abundant together with Selaginella densa and several species of bog orchids, along the Louden Creek bed and the eastern flats of the North Saskatchewan River.

\subsubsection{Whirlpool Point}

The area around Whirlpool Point (Figure 1) is geologically diverse, ranging from riparian mud flats to the lower borders of the subalpine treeline. Wetlands and grasslands contain a great diversity of plant species. Calcareous outcrops support Cheilanthes feei in this area. At higher elevations, hybridization appears to have occurred between Pinus contorta and $P$. flexilis evident by pine cones which are morphologically intermediate between these two species.

\subsubsection{Dune Fields}

The dune fields area south of the Siffleur Falls trail and between the North Saskatchewan River valley and the Siffleur River valley is an old burn area (Figure 1). It is dominated by Pinus contorta with a thick understorey consisting of Shepherdia canadensis and other common boreal forest species on a calcareous mineral substrate. The terrain contained ridges separated by drainage areas with a prominent component of Salix species. The orchid Goodyera repens was found in two sites in this area of interest.

\subsubsection{Wetlands}

Several large wetlands in the far south-east area of the Ecological Reserve were also investigated (Figure 2). These wetland sites are extremely important to animal populations in the area. Tracks were numerous and signs of browsing and wallowing were evident. These areas were fairly productive, but diversity was relatively low. Only one (Wetland 1, plot 54) out of three wetlands was formally described with site and vegetation forms. The other two wetlands (wetlands 2 and 3) were visually inspected and their descriptions are in the following subsections. It was felt that these areas were important to describe but no unusual species were found. Carex buxbaumii (S3), C. lasiocarpa (S3), C. livida (S3) and C. viridula (S3), found in these wetland areas, are notably rare but are currently not being tracked on the rare or endangered checklists for Alberta (as of November 1996).

\subsubsection{Wetland 2 (52 $\left.00^{\prime} 50^{\prime \prime} \mathrm{N}, 116^{\circ} 22^{\prime} 55^{\prime \prime} \mathrm{W}\right)$}

This wetland of very dry marl substrate was colonized by clumps of Juncus alpinoarticulatus and Carex viridula with some Potamogeton species left stranded. Enclosing the marl area is an extensive sedge meadow (fen) consisting largely of Carex utriculata with bands of $C$. lasiocarpa and $C$. aquatilis intermingled. C. livida also occurred sparsely across the marl. A band of Calmagrostis montanenis was found at the north end. Shrub species surrounding the sedge meadow area included Betula glandulosa, Potentilla spp., Salix glauca, S. maccalliana, S. 
myrtillifolia, and S. candida. Also, Deschampsia cespitosa, Scirpus acutus, Polygonum amphibium, Carex capillaris, and Juncus balticus were abundant in the edge vegetation which graded out toward a lodgepole pine forest.

\subsubsection{Wetland $3\left(52^{\circ} 01^{\prime} 00^{\prime \prime} \mathrm{N}, 116^{\circ} 22^{\prime} 55^{\prime \prime} \mathrm{W}\right)$}

This area was slightly wetter than the previous wetland and consisted of an open, shallow marl pond surrounded by a lodgepole pine forest. The pond had a band of Carex viridula around its edges, occasionally occurring with $C$. aquatilis. $C$. viridula was also abundant on the upper shore along with $C$. aurea, while C. capillaris was found locally on round mounds. Waterfowl were present in the open water of the pond with Potamogeton filiformis occurring abundantly. Juncus alpinoarticulatus again colonized the drier marl toward the edges. Potentilla anserina, Habenaria hyperborea, Pedicularis groenlandica, Calamagrostis montanensis, Carex concinna, Carex buxbaumii and Erigeron spp. also were present. 



\subsection{CONCLUSION}

\subsection{Comparison of Studies}

In this survey, a late and cold spring compounded by a dry summer may have contributed to the absence of species reported in both earlier studies. Similarly, Wallis and Wershler (1981) did not find either the diversity of species or the abundance of individuals reported by Kondla (1979) in his earlier study. Most plants in this study were either not flowering, or had flowered earlier, making identification and location difficult. Bruhjell et al. (1996) cited similar problems in detecting rare plants in the study area.

Several species found in the previous two studies (e.g., Botrychium dusenii, Castilleja pallida, Hippuris montana, Ledum glandulosum, Pellaea glabella, and Senecio cymbalarioides) were not recorded in this study. However, several new species of concern (e.g., Brachythecium albicans, Erysimum asperum, Haplopappus lyallii, Hieracium cynoglossoides, and Salix lanata) not reported in the previous studies were found in this survey. Future surveys may relocate populations reported by the previous two studies as well as additional populations of rare and endangered plants.

Hippuris montana, which was reported to be present in the Whirlpool Point Fen by Wallis and Wershler (1981), was not found in this study. The only Hippuris found in that area was the common $H$. vulgaris; however, this does not mean that $H$. montana is no longer present in the area. A survey performed in a different year or at a different period of the year may yet detect this species where it was originally reported.

Wallis and Wershler (1981) found some taxonomic confusion with Agropyron smithii and concluded that it may hybridize within the study area. This report confirms their finding. A. smithii warrants an in depth taxonomic study to determine its taxonomic status in Alberta.

Both Kondla (1979) and Wallis and Wershler (1981) found Primula mistassinica on the mud flats. P. mistassinica was not found in any of the plots of this survey; however, it was found in an area outside of the ecological reserve.

\subsection{Recommendations}

Some rare and endangered species were previously found in the area, but were not found in this study, either because the number of individuals were too few or the late spring and dry summer made identification impossible. Future floristic surveys of the area will probably locate rare and endangered plant populations not found in this survey. Site visits throughout the growing season and across several years will probably result in additional populations of species of concern. The significant areas identified within this region are important for both plant species abundance and support of animals which depend on them.

The riparian zones, particularly along the North Saskatchewan River, seem to support the greatest diversity of plant species. These habitats also have the greatest potential for rare and endangered species, as evidenced in this and other surveys. These areas should be managed carefully within the ecological reserve in order to maintain viable plant populations and sustaining ecosystems. Managers of the reserve may want to consider limiting access to these sensitive areas. 

An area of interest outside of the Kootenay Plains Ecological Reserve is White Goat Lake, north of the David Thompson Resort. This area consists of a rich fen area fed by a shallow stream. The entire area is highly calcareous including the stream. Both Salix lanata var. calcicola and Primula mistassinica (S1 and S2 respectively) were found supporting the contention that both species may be abundant north of the ecological reserve as noted by Kondla (1979). Therefore, it is recommended that this area be protected due to the presence of both these plants. In the eastern section of the fen tire tracks were found.

Wallis and Wershler (1981) considered the Kootenay Plains ecosystem to be the result of a unique combination of physiography, climate, fire, grazing and groundwater which interact to form conditions that favour the development and persistence of grassland communities. It is likely that two of these factors-fire and grazing have changed considerably since the arrival of Europeans.

Wallis and Wershler note that the presence of seral lodgepole pine stands throughout the North Saskatchewan Valley suggests that fire is (or was) a regular occurrence in the area. White, Paquet and Purves (1994) suggest that warm montane sites in the eastern slopes of the Rockies may have had about a 40 year fire interval prior to the arrival of Europeans. Fire frequency in the valley is has been greatly reduced and it is possible that the extent and severity of fires have changed considerably as well.

Historically, there is much evidence to suggest that the North Saskatchewan Valley has been a favoured wildlife habitat area. There are several historical references to large populations of ungulates using the area (Wallis and Wershler 1981). Palliser (1863 in Wallace \& Wershler, 1981) noted the presence of large populations of sheep, wapiti, deer and moose using the area at a time when game when generally scarce in the Rockies. Given the historically high usage of the area, it is likely that heavy grazing contributed to some extent to the persistence of grassland communities.

More recently, the area has been subject to heavy feral and domestic horse grazing up until 1979 or 1980 . Wallace \& Wershler (1981) suggest that recent horse grazing may have been severe relative to historical levels of use by wildlife. This may have led to a reduction in species diversity and increased soil exposure, which may tend to make the sites somewhat drier. The vegetation in the Kootenay Plains bear a strong resemblance to a KoeleriaCalamagrostis montanensis community identified by Stringer (1973), which he considers to be a community that is maintained in part by grazing. Wallis and Wershler conducted a survey of aerial photographs taken of the Kootenay Plains in 1951 and 1981. There was little apparent change in the extent of the grassland communities. Presumably the relatively recent horse grazing has served the same role as the historic wildlife populations in maintaining the grassland communities.

One can thus conclude that fire and grazing have played an important role in maintaining the unique vegetation communities of the Kootenay Plains. Given that the fire frequency has been greatly reduced, if not eliminated and that the grazing pressure by domestic horses has been reduced, it is not unreasonable to expect that successional changes may occur in the grassland communities. These two factors are not the sole determinants of community structure, climate and surficial geology also play an important part. 
It is recommended that a monitoring program be established to determine what, if any successional changes are occurring in the ecological reserve. A good first step would be to use current and historical aerial photography as a means of assessing any forest community change as well as any invasion of grassland communities. Thorough vegetation sampling throughout the area should be undertaken to establish a baseline description of the presentday vegetation. Such data could then be compared with previously collected vegetation data. If the data indicates that successional change is occurring and such change could potentially affect any rare species or communities, reintroduction of controlled burns and grazing should be considered. 


\subsection{REFERENCES}

Alberta Environmental Protection. 1994a. Ecological land survey site description manual. Resource Information Branch, Finance, Land Information and Program Support Services, Alberta Environmental Protection.

Alberta Environmental Protection. 1994b. Natural regions and subregions of Alberta. 1:1,000,000 scale map. Land Information Services, Edmonton, Alberta.

Alberta Environmental Protection. 1994c. Sheet No. 82 N/16. 1:50,000 scale resource access map. Information Resource Management Services, Edmonton, Alberta.

Alberta Environmental Protection. 1994d. Sheet No. 83 C/1. 1:50,000 scale resource access map. Information Resource Management Services, Edmonton, Alberta.

Alberta Parks. 1995. Alberta Natural Heritage Information Centre tracking list: mosses of special concern. Alberta Natural Heritage Information Centre (NHIC). May 1995. Edmonton, Alberta.

Alberta Parks. 1996. Provincial tracking list of vascular plant species of concern in Alberta. Alberta Natural Heritage Information Centre (NHIC). June 1996. Edmonton, Alberta.

Bruhjell, D.R., J.A. Bentz, R. Shultz and A. Saxena. 1996. Biophysical and significant ecological features of the Kootenay Plains Ecological Reserve. Prepared for Resource Data Division, Alberta Environmental Protection. GEOWEST Environmental Consultants Ltd.

Ireland, R.R. 1982. Moss Flora of the Maritime Provinces. National Museums of Canada, National Museum of Natural Sciences, Publications in Botany, No. 13. Ottawa, Ontario.

Kondla, N.G. 1979. Special resource features map and vegetation map of the Kootenay Plains. Dept. of Recreation \& Parks.

Looman, J. and K.F. Best. 1979. Budd's Flora of the Canadian Prairie Provinces. Research Branch Agriculture Canada, Publication 1662.

Moss, E.H. 1983. Flora of Alberta: a manual of flowering plants, conifers, ferns, and fern allies found growing without cultivation in the Province of Alberta, Canada. $2^{\text {nd }}$ edition. Revised by J.G. Packer. University of Toronto Press, Toronto, Ontario.

Packer, J.G. and C.E. Bradley. 1984. A checklist of the rare vascular plants in Alberta. Provincial Museum of Alberta, Natural History Occasional Paper No. 5.

Strong, W.L. 1992. Ecoregions and ecodistricts of Alberta. Vol. 1. Prepared for Alberta Forestry Lands and Wildlife, Land Information Services Division, Resource Information Branch. W.L. Strong Ecological Land Surveys Ltd.

Wallis, C. and C. Wershler. 1981. Kootenay Plains flora and grassland vegetation assessment. Prepared for Natural Areas Program, Energy \& Natural Resources. Cottonwood Consulting.

White, C.A., P. Paquet and H.D. Purves. 1994. Nursing Humpty's syndrome: Bow Valley ecosystem restoration. Ecological restoration of national parks: proceedings of a symposium at the fourth annual conferance of the Society for Ecological Restoration, 10-14 August 1992, University of Waterloo, Waterloo, Ontario. 
APPENDIX 1

Distribution of plots over serveral ecological features and plant community types

\begin{tabular}{|c|c|c|c|c|c|c|c|c|}
\hline Plot \# & Elevation & Aspect & Slope & Macro-position & Meso-position & Site shape & Successional status & Plant community type \\
\hline 01 & 4400 & 138 & 15 & valley floor & lower to upper slope & straight & pioneer seral & JUNIHOR/ARTIFRIG-ASTEALP \\
\hline 02 & 4400 & & 0 & valley floor & level & straight & pioneer seral & JUNIHOR/AGRODAS \\
\hline 03 & 4400 & 223 & 12 & valley floor & middle slope & straight & pioneer seral & KOELMACIARTFRIG \\
\hline 04 & 4400 & 140 & 5 & valley floor & level & straight & young seral & AGRODAS-KOELMAC/ARTEFRI \\
\hline 05 & 4400 & & 0 & valley floor & level & straight & young seral & SW/JUNIHOR/OXYTSPL \\
\hline 08 & 4400 & 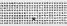 & o & valley floor & level & Stratgh! & young seral & SWIAGRODASIOXYTSPP \\
\hline 07 & 4400 & 40 & 12 & plain & lower slope & straight & young seral & Sw(PI)/JUNIHOR/feather moss \\
\hline 08 & 4400 & 130 & 1 & valley floor & level & straight & pioneer seral & AGRODAS-KOELMAC \\
\hline 09 & 4400 & 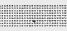 & 0 & valley floor & level & straight & pioneor seral & KOELMAC-AGRODASIGENTAMA \\
\hline 10 & 4400 & 170 & 6 & valley floor & upper slope & convex & pioneer seral & ARCTUVAVANTEPAR \\
\hline 11 & 4400 & 100 & 8 & valley floor & level & straight & young seral & SW/ARCTUVA-JUNIHOR/ANTEPAR \\
\hline 12 & 4400 & 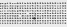 & 0 & valley floor & level & straight & piomeer seral & AGRODAS/Forbs \\
\hline 13 & 4400 & 250 & 20 & valley floor & middle slope & convex & pioneer seral & JUNIHOR/AGRODAS-KOELMAC \\
\hline 14 & 4400 & 302 & 6 & valley floor & level & straight & pioneer seral & AGROSMI-AGRODAS \\
\hline 15 & 4400 & & 0 & valley floor & level & straght & pieneer seral & KOELMAC-AGROSUII \\
\hline 16 & 4400 & 125 & 25 & valley floor & toe & straight & young seral & ARCTUVA-ELAECOM/forbs \\
\hline 17 & 4500 & 290 & 20 & lower slope & lower slope & concave & young seral & ARCTUVA-JUNIHOR-ELAECOM \\
\hline 18 & 4600 & 299 & 8 & lower slope & lower slope. & straight & Young seral & ELAECOM-ARCTUVANANTEPAR \\
\hline 19 & 4400 & & 0 & valley floor & level & straight & pioneer seral & ARCTUVAVANTEPAR-SMILSTE \\
\hline 20 & 4400 & 120 & 2 & valley floor & level & straight & pioneer seral & BETUGLA-POTEFRU/CARESPP \\
\hline 21 & 4400 & $\because$. & 0 & valley floor & level & straight & pioneer seral & BETUGLACARESPP \\
\hline 22 & 4400 & 140 & 2 & valley floor & level & straight & pioneer seral & BETUGLA-POTEFRU/CARESPP \\
\hline 23 & 4500 & 182 & 14 & valley floor & level & straight & pioneer seral & ARCTUVAIAGROSMI/forbs \\
\hline 24 & 4400 & 130 & 7 & valley floor & level: & straght & plofeer seral & JUNHORAGROSMVIorbs \\
\hline 25 & 4400 & & 0 & valley floor & level & straight & young seral & Pb/JUNIHOR/KOELMAC \\
\hline 26 & 4400 & 100 & 2 & valley floor & level & straight & pioneer seral & AGRODAS-kOELMAC \\
\hline 27 & 4400 & 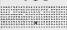 & 0 & valley floor & level & straight & mature seral & PUUUNIHOR-SHEPCAN \\
\hline 28 & 4500 & 144 & 4 & lower slope & lower slope & straight & mature seral, young edaphic climax & PI/SHEPCAN/ELYMINN \\
\hline 29 & 4600 & 148 & 6 & lower slope & crest & convex & mature seral, young edaphic climax & PI/ARCTUVA \\
\hline 30 & 4500 & 150 & 5 & valley foor & level & straight & mature seral & PIARCTUVA-SHEPCANELYMINN \\
\hline 31 & 4400 & . & 0 & valley floor & level & straight & young seral & SwIARCTUVA/grasses/ANTEPAR \\
\hline 32 & 4400 & . & 0 & valley floor & level & straight & young seral & Sw/BETUGLA/forbs \\
\hline 33 & 4400 & & 0 & valley floor & lovel & straight & mature seral & CARECON-CALAMON \\
\hline 34 & 4400 & 209 & 21 & valley floor & upper slope & straight & mature seral & Pf/ARCTUVA \\
\hline 35 & 4400 & & 0 & valley floor & level & straight & mature seral & Sw/BETUGLA-ARCTUVA/forbs \\
\hline 36 & 4700 & 302 & 36 & middle slope & midole slope & straight & mature seral & PUJUNHHOR-JUNICOM \\
\hline 37 & 4300 & . & 0 & valley floor & level & straight & mature seral & Sw/POTEFRU/forbs \\
\hline 38 & 5800 & 183 & 22 & apex & crest & convex & young seral & ARCTUVA-JUNICOM/forbs \\
\hline 39 & 6000 & 272 & 42 & apex & upper slope & straight & mature seral & PINUFLE-JUNLOM-ARCTUVADRYAOCT \\
\hline 40 & 4400 & . & 0 & valley floor & level & straight & young seral & BETUGLA-POTEFRU \\
\hline 41 & 4400 & & 0 & valley floor & level & convex & young seral & ELAECOM/grasses \\
\hline 42 & 4400 & & 0 & valley floor & level & straight & mature seral & SEISALISPP ARCTUVAVEYMNN \\
\hline 43 & 4400 & & 0 & valley floor & level & straight & mature seral & POTEFRU/CARESCO \\
\hline 44 & 4400 & 58 & 74 & upper slope & middle slope & concave & young seral & POPUTRE-JUNICOM/ELYMINN \\
\hline 45 & 4400 & 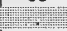 & 0 & valley foor & level & straight & young seral & JUNIIIOR/CARESCIMHUUIABI \\
\hline 46 & 4400 & & 0 & valley floor & depression & straight & mature seral & Sw-PI/SHEPCAN/graminoids \\
\hline 47 & 4400 & & 0 & valley floor & level & straight & mature seral & ARCTUVA/grasses \\
\hline 48 & 4400 & & 0 & valley floor & level & entcave & young sectal & BETUELA ELAECOM/graminoidsiforbs \\
\hline 49 & 4875 & 334 & 32 & middle slope & upper slope & convex & mature seral & PI/SHEPCAN/ELYMINN \\
\hline 50 & 4830 & 60 & 30 & middle slope & middle slope & straight & mature seral & PI/SHEPCAN/ELYMINN \\
\hline 51) & 4300 & & 0 & valley floor & level & stratght & young seral & SW/SALIBRA-POTEFRUIFOHBSIUNCBAL \\
\hline 52 & 4300 & & 0 & valley floor & level & straight & young seral & POTERU/CARESPP \\
\hline 53 & 4300 & & 0 & valley floor & level & straight & young seral & POTERU/CARESPP/EQUIPAL \\
\hline 54 & 4000 & Fi & 0 & valley floor & depression & stralght & young seral young edaphle climax & BETUGLASAUCANELEOOUUPEDIGRO \\
\hline
\end{tabular}





\section{APPENDIX 2}

Rare native plant survey forms 


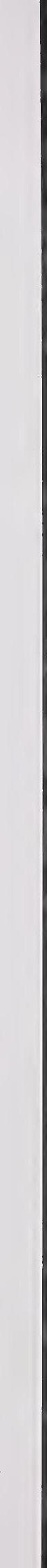




\section{Rare Native Plant Survey Form}

Please enter all information available to you. Use the back for comments if necessary. Please attach or draw a map on the back. Return To: Heritage Protection and Education Branch, Alberta Parks, 8th Flr, 10405 Jasper Ave, Edmonton T5J 3N4.

Scientific Name: Haflopepus uniflorus Code: PDASTDTDK

Common Name: One- flowered Lranplant

Reporter: E. Gordon Address: $15216-74$ St, Edm

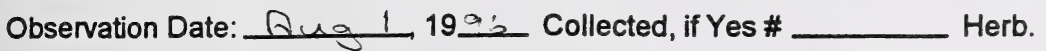

Phone: $475-2565$

Municipality: Kootenay Plains.

Mapsheet: $83 \mathrm{Cl}$

Legal Twp: 35 Rge: 17 W 5 M: Section: 31 LSD: 8

Twp:_ Rge: _ _ W M S Section:__ LSD:

Lat.: $52^{\circ} 02^{\prime} 54^{\prime \prime}$ Long.: $116^{\circ} 24^{\prime} 33^{\prime \prime}$ Elevation: 4400 (ft $\left./ \mathrm{m}\right)$

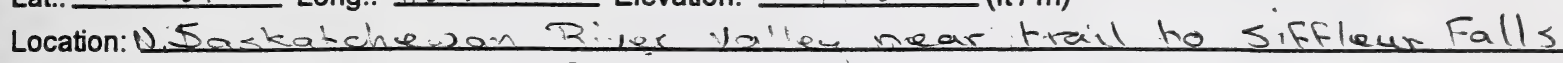
en west side of river

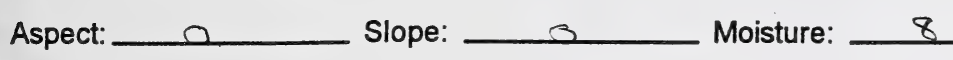

Habitat: Mead'ow

Plant Community: Grassland

commurity Acc.\#

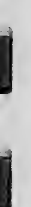




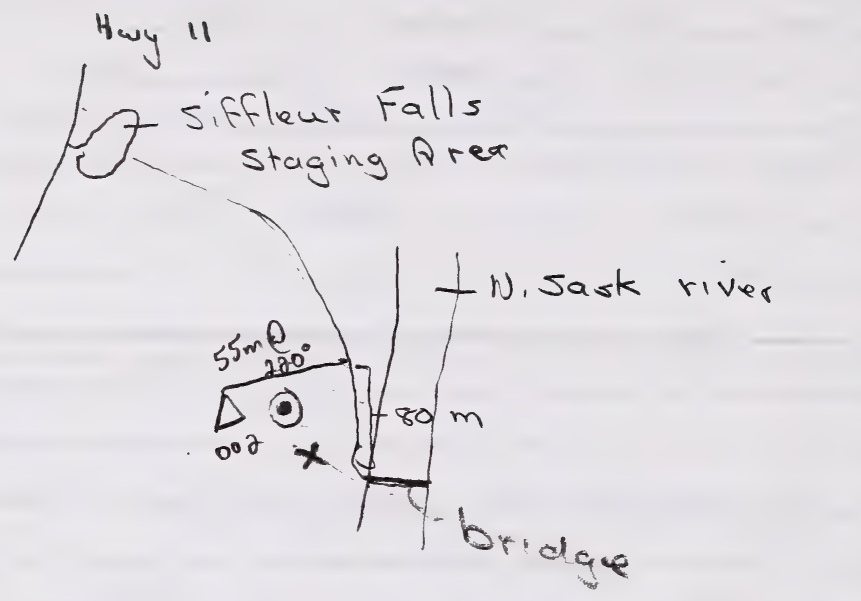

$x$ bearing to $328^{\circ} \sim 30 m$ to rebar $(9)$ 


\section{Rare Native Plant Survey Form}

Please enter all information available to you. Use the back for comments if necessary. Please attach or draw a map on the back. Return To: Heritage Protection and Education Branch, Alberta Parks, 8th Flr, 10405 Jasper Ave, Edmonton T5J 3 N4.

Scientific Name: Haplopappus uniflorus Code: PDASTDT OKØ

Common Name: ane-flowered Ironplant

Reporter: E. Gordon Address: 15216-74 St. Edm

Observation Date: Aug 3,1996 Collected, if Yes \#__ Herb.

Phone: $475-2565$

Municipality: Kootenay Plains.

Mapsheet: $83<1$

Legal Twp: 35 Rge: 17 W 5 M: Section: 31 LSD: 8

Twp:__ Rge: _ _ W _ M: Section:__ LSD:

Lat.: $52^{\circ} 02^{\prime} 58^{\prime \prime}$ Long.: $116^{\circ} 24^{\prime} 36^{\prime \prime}$ Elevation: 4400 (ft/m)

Location: Neas Populus tremuloides stonel en west side of 1) sasle Piver near trail to siffleur Falls

Aspect:_ Slope: Co Moisture:

Habitat: Meadow

Plant Community: Grasstand/Forb

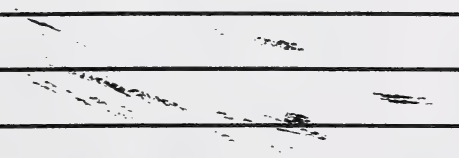

Landowner:

\# of Individuals:

Is this a subsequent visit: no yes

Compared to last visit: more;___ same; fewer.

Phenology:__ \# vegetative; __ \# adults ; _ \# \#uveniles; __ \# others; _ \# \#lowering; 3 \# fruiting Current Land Use / Possible Threats: Some tromplung and mountain bike threat may be possible if people leave trail

Should / could this site be protected? :

How?

Determination:

keyed at site; give reference used:

compared with specimen housed at: $U$ of $A$ herbarium

compared with photo/drawing in:

$x$ by another person (name): Patsy Cotterill other:

Photographs:

$\times$ Habitat Slide

Date Received

Date Entered 


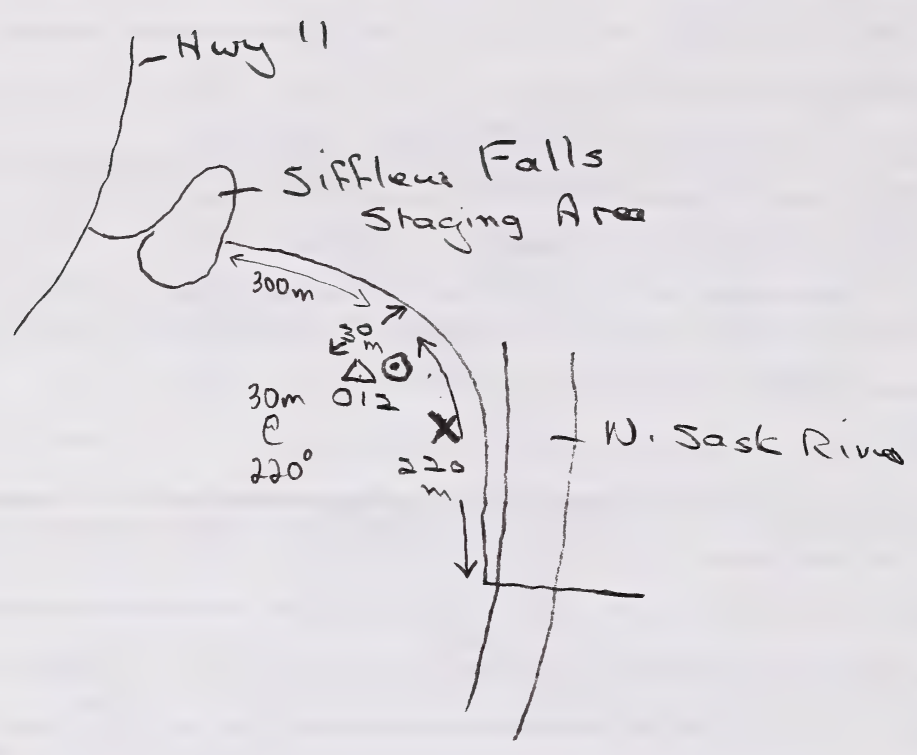

Xbeang g tree $333^{\circ} \sim 50 m$ to rebar $\odot$ 


\section{Rare Native Plant Survey Form}

Please enter all information available to you. Use the back for comments if necessary. Please attach or draw a map on the back. Return To: Heritage Protection and Education Branch, Alberta Parks, 8th Flr, 10405 Jasper Ave, Edmonton T5J 3N4.

Scientific Name: Haplopappus uniflorus Common Name: Ine flowered Ironplant Code: PDASTDTDK, Reporter: E. Gordon Address: $15216-74$ St. Edm Observation Date: Aug 5, 1996 Collected, if Yes \#. Herb. Phone: $475-2565$ Municipality: Kootenay Plains. Mapsheet: $\& \leq \subset 1$

Legal Twp: 35 Rge: 17 W 5 M: Section: 20 LSD: 6

Twp:__ Rge: _ W W M S Section:__ LSD: Lat.: $52^{\circ} 01^{\prime} 56^{\prime \prime}$ Long.: $116^{\circ} 25^{\prime} 26^{\prime \prime}$ Elevation: 4400 ( $\left.\mathrm{ft} / \mathrm{m}\right)$ Location: On west side of $N$. Sask. Rliver on mudflats approximably $110 \mathrm{~m}$ from Hiahway 11 Aspect:_ O Slope: 0 Moisture:

Habitat: Riverine mud flats

Plant Community: Sedae Cowanemity

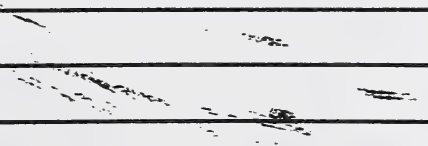

Landowner:

\# of Individuals: Is this a subsequent visit: no yes

Compared to last visit: more; same; fewer. Phenology:__ \# vegetative; __ \# adults ; _ \# \#uveniles; __ \# others; __ \# flowering; _ _ \# fruiting Current Land Use / Possible Threats: Flooding

Should / could this site be protected? : How?

Determination:

keyed at site; give reference used:

$x$ compared with specimen housed at: $u$ of $A$ herbarium compared with photo/drawing in:

$x$ by another person (name): Patsy Cotterill other: Photographs: 


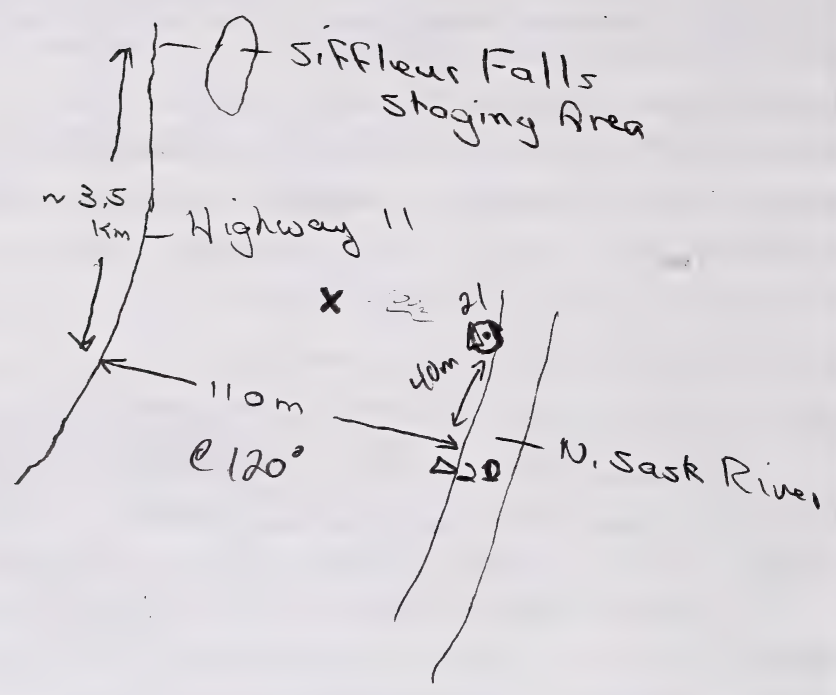

$x$ bearing trea $114^{\circ}$ to rebar 6 $\sim 100 \mathrm{~m}$ 


\section{Rare Native Plant Survey Form}

Please enter all information available to you. Use the back for comments if necessary. Please attach or draw a map on the back.

Return To: Heritage Protection and Education Branch, Alberta Parks, 8th Flr, 10405 Jasper Ave, Edmonton T5J 3N4.

Scientific Name: Happlopappus uniflorus

Code: PDASTDTQKळ

Common Name: One flowered I ronplant

Reporter: E. Gordon Address: $15216-74 \mathrm{sh}$. Edm Phone: $475-2565$

Observation Date: Aug 6, 1996 Collected, if Yes \# Herb. Acc.\#

Municipality: Kostenay Ploins

Mapsheet: $83 \subset 1$

Legal Twp: 35 Rge: 18 W 5 M: Section: 14 LSD: 8

Twp:__ Rge: ___ W__ M: Section:__ LSD:

Lat:: $52^{\circ} 00^{\prime} 20^{\prime \prime}$ Long.: $116^{\circ} 27^{\prime} 29^{\prime \prime}$ Elevation: $4400(\mathrm{ft} / \mathrm{m})$

Location: $2.6 \mathrm{~km}$ is of Whirlpeol Point on Riverbank

Aspect:___ Slope:

Habitat:Shrent-

Plant Community: Salix Tetula Wabenaria Commanity

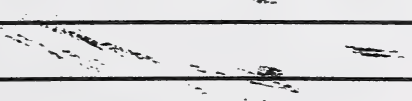

Landowner:

\# of Individuals: 6 Is this a subsequent visit: ก0 yes

Compared to last visit: more; same; fewer.

Phenology:___ \# vegetative; ___ \# adults ; __ \# juveniles; __ \# others; __ \# flowering ; 6 \# fruiting Current Land Use / Possible Threats: None

Should / could this site be protected? : How?

Determination:

keyed at site; give reference used:

$x$ compared with specimen housed at: compared with photo/drawing in:

$x$ by another person (name):

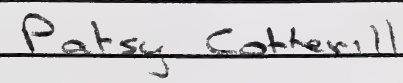
other:

Photographs: 


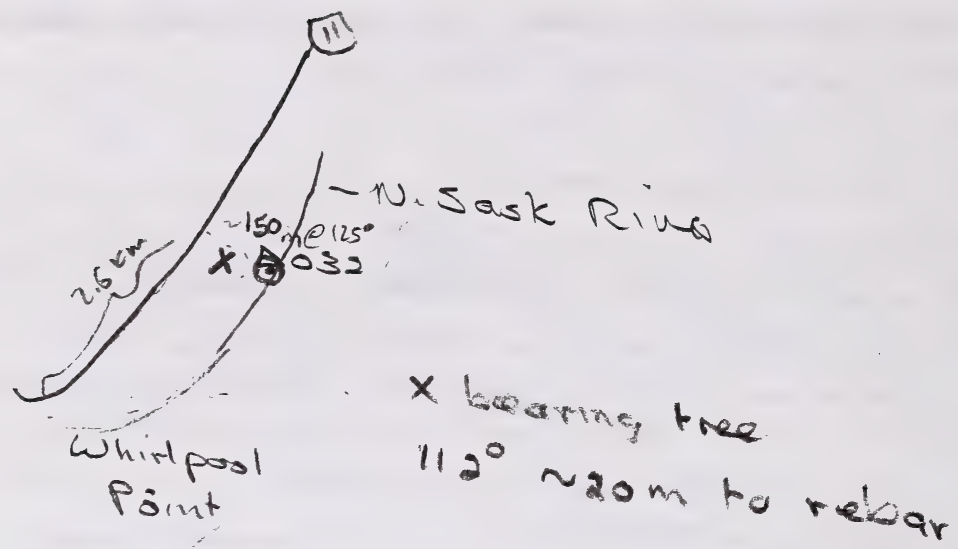




\section{Rare Native Plant Survey Form}

Please enter all information available to you. Use the back for comments if necessary. Please attach or draw a map on the back. Retum To: Heritage Protection and Education Branch, Alberta Parks, 8th Flr, 10405 Jasper Ave, Edmonton T5J 3N4.

Scientific Name: Haplopappus uniflorus Code: PDASTDTDKO

Common Name: One fio wered Ironplant

Reporter: E, Gordon Address: $15216-74 \mathrm{st}$ Edm Observation Date: Aug 16,1996 Collected, if Yes \# Herb. Phone: $475-2565$ Municipality: Kostenay Plains.

Mapsheet: $83 \subset 1$

Legal Twp: 35 Rge: 18 W 5 M: Section: 14 LSD: 8

Twp:__ Rge: ___ W__ M: Section:__ LSD:

Lat:: $52^{\circ} 00^{\prime} 20^{\prime \prime}$ Long.: $116^{\circ} 27^{\prime} 21^{\prime \prime}$ Elevation: 4300 $(\mathrm{ft} / \mathrm{m})$

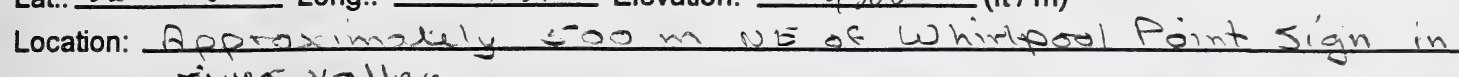
river valley

Aspect: 0 Slope: O Moisture:

Habitat: oreliel rich drainace channel

Plant Community: Sedae /Ordid

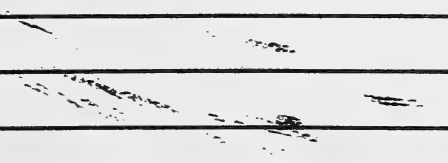

Landowner: -

\# of Individuals:

8 is this a subsequent visit: no yes

Compared to last visit: more;___ same; fewer.

Phenology: $\underline{I}$ \# vegetative; __ \# adults ; __ \# juveniles; __ \# others; _ _ \# flowering; $\$$ \# fruiting Current Land Use / Possible Threats: None

Should / could this site be protected? :

How?

Determination:

keyed at site; give reference used:

compared with specimen housed at:

compared with photo/drawing in:

$x$ by another person (name): Patse Cotterill other:

Photographs:

$x$ Habitat

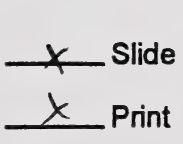

Date Received

Date Entered 


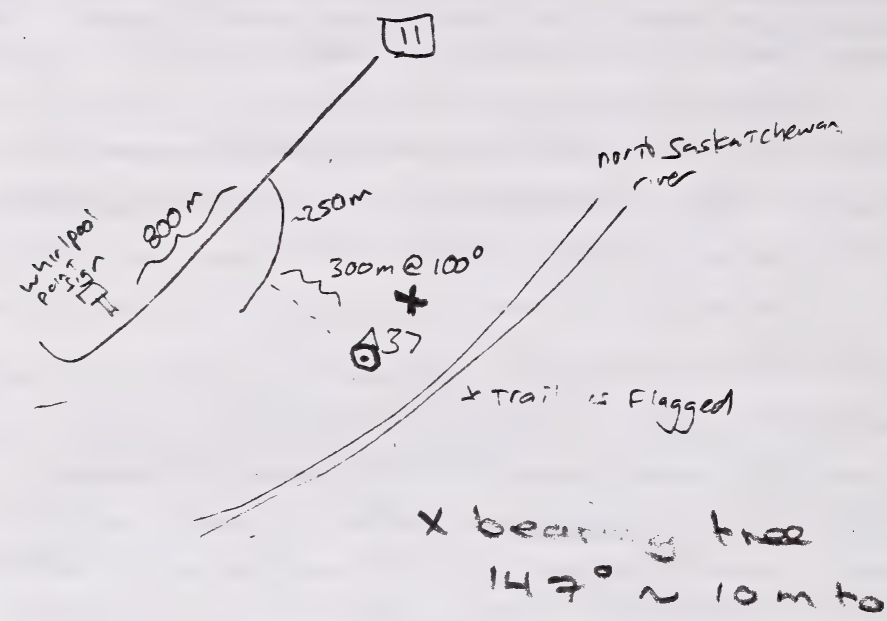
rebar 0 
Please enter all information available to you. Use the back for comments if necessary. Please attach or draw a map on the back. Retum To: Heritage Protection and Education Branch, Alberta Parks, 8th Flr, 10405 Jasper Ave, Edmonton T5J 3N4.

Scientific Name: Haclecappus unifigrus Code: PDASTDT QKE

Common Name: One filswered I Oralant

Reporter: E. Gordon Address: $15116-74 \leq t$. Edm Phone: $475-2565$ Observation Date: Ruse 17,1996 Collected, if Yes \# Herb. Acc.\#

Municipality: Kaston ay Plains

Mapsheet: $8 \leqslant 1$

Legal Twp: 25 Rge: 17 W S M: Section: 32 LSD: 7

Twp:__ Rge: __ W_ M: Section:__ LSD:

Lat: $52^{\circ} 02^{\prime} 57^{\prime \prime}$ Long.: $116^{\circ} 23^{\prime} 28^{\prime \prime}$ Elevation: 4400 ( $\left.4 \mathrm{ft} / \mathrm{m}\right)$

Location: Appraximalely $40 \mathrm{~m}$ North of 5 ifCleur Falls tri. footbridge an west bank of sifitour rivios

Aspect:_ Slope: $\quad 0$ Moisture:

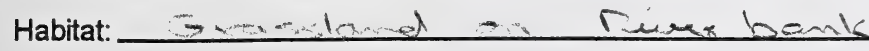

Plant Community: Grasses/ Forbs

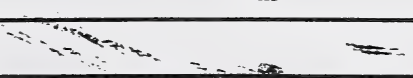

Landowner:

\# of Individuals:

Is this a subsequent visit: no yes

Compared to last visit: more; same; fewer.

Phenology: 2 \# vegetative; __ \# adults ; __ \# juveniles; __ \# others; __ \# flowering ; 1 \# fruiting Current Land Use / Possible Threats: Wuman disturbence (fire) in anea

Should / could this site be protected? : How?

Determination:

keyed at site; give reference used:

compared with specimen housed at:

compared with photo/drawing in:

$x$ by another person (name): Patsy cotterill other:

Photographs:

\begin{tabular}{ll}
$x$ Habitat & $x$ Slide \\
\cline { 1 - 1 } Diagnostic Feature & $x$ Print
\end{tabular}




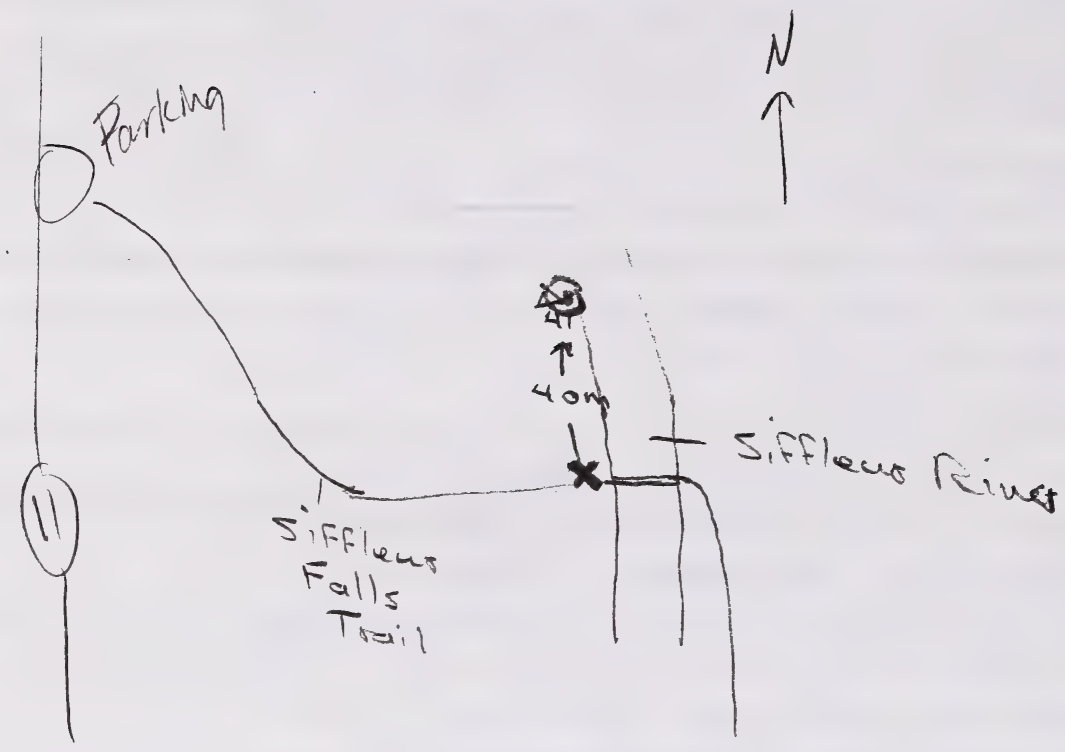

$X$ bearing tree

$\sim 30 \mathrm{~m}$ to re wa? 


\section{SAS Summary}

\begin{tabular}{|c|c|c|c|c|c|c|c|c|c|c|c|c|}
\hline & & & & M & & & & & & & & \\
\hline & & & M & E & & S & & M & & $\mathbf{M}$ & & $\begin{array}{l}R \\
N\end{array}$ \\
\hline & & & $\mathrm{E}$ & A & $S$ & $\mathrm{~T}$ & M & I & M & A & $\mathbf{R}$ & $\mathrm{N}$ \\
\hline & & & A & $\mathrm{N}$ & $\mathrm{T}$ & D & I & $\mathrm{N}$ & A & $\mathrm{X}$ & $\mathrm{N}$ & G \\
\hline$F$ & $P$ & $F$ & $\mathrm{~N}$ & L & D & L & $\mathrm{N}$ & L & $\mathrm{x}$ & L & G & L \\
\hline$I$ & L & $\mathrm{R}$ & L & 0 & L & 0 & L & 0 & L & 0 & L & 0 \\
\hline L & 0 & $E$ & A & $\mathrm{N}$ & A & $\mathrm{N}$ & A & $\mathrm{N}$ & A & $\mathrm{N}$ & A & $\mathrm{N}$ \\
\hline$E$ & $T$ & 0 & $\mathrm{~T}$ & G & $\mathrm{T}$ & G & $\mathrm{T}$ & G & $\mathrm{T}$ & G & $\mathrm{T}$ & G \\
\hline
\end{tabular}

K091416B $02 \quad 53 \quad 54.0028 \quad 33.1482 \quad 0.06082 \quad 0.44996 \quad 53.930 \quad 32.229 \quad 54.138 \quad 33.841 \quad 0.208 \quad 1.612$

$\begin{array}{lllllllllllllll}\mathrm{K} 091416 \mathrm{~A} & 12 & 63 & 57.8931 & 36.0903 & 0.43363 & 0.25565 & 57.182 & 35.530 & 58.574 & 36.451 & 1.392 & 0.921\end{array}$

$\begin{array}{llllllllllllllll}\text { K091516A } & 21 & 54 & 55.9274 & 25.7266 & 0.08983 & 0.06532 & 55.687 & 25.660 & 56.004 & 25.889 & 0.317 & 0.229\end{array}$

$\begin{array}{llllllllllllll}\text { K091515B } & 35 & 58 & 20.0975 & 29.3676 & 0.36992 & 0.25653 & 19.455 & 28.802 & 20.636 & 29.628 & 1.181 & 0.826\end{array}$

$\begin{array}{lllllllllllll}\mathrm{K} 091515 \mathrm{C} & 37 & 56 & 20.4312 & 20.7848 & 0.09930 & 0.33412 & 20.206 & 20.112 & 20.587 & 21.239 & 0.381 & 1.127\end{array}$

K091417A $415256.8333 \quad 27.9018 \quad 0.20538 \quad 0.26470 \quad 56.440 \quad 27.614 \quad 57.074 \quad 28.419 \quad 0.634 \quad 0.805$

STD $=$ standard deviation

RNG = range

MIN = minimum

MAX = maximum

note: Latitude (LAT) and longitude (LONG) variables represented here are for seconds only. Degrees and minutes were excluded from these summaries.

PFINDER Summary

\begin{tabular}{cccc}
\hline GPS file & $\begin{array}{c}\text { Plot } \\
\text { number }\end{array}$ & $\begin{array}{c}\text { Number of } \\
\text { points collected }\end{array}$ & $\begin{array}{c}\text { Largest range of points collected } \\
\text { (measured in metres using } \\
\text { PFINDER) }\end{array}$ \\
\hline \hline K091416B & 02 & 53 & 31.3 \\
K091416A & 12 & 63 & 43.1 \\
K091516A & 21 & 54 & 10.7 \\
K091515B & 35 & 58 & 39.3 \\
K091515C & 37 & 56 & 24.5 \\
K091417A & 41 & 52 & 24.9 \\
\hline \hline
\end{tabular}



Plot locations for all detailed floristic survey sites

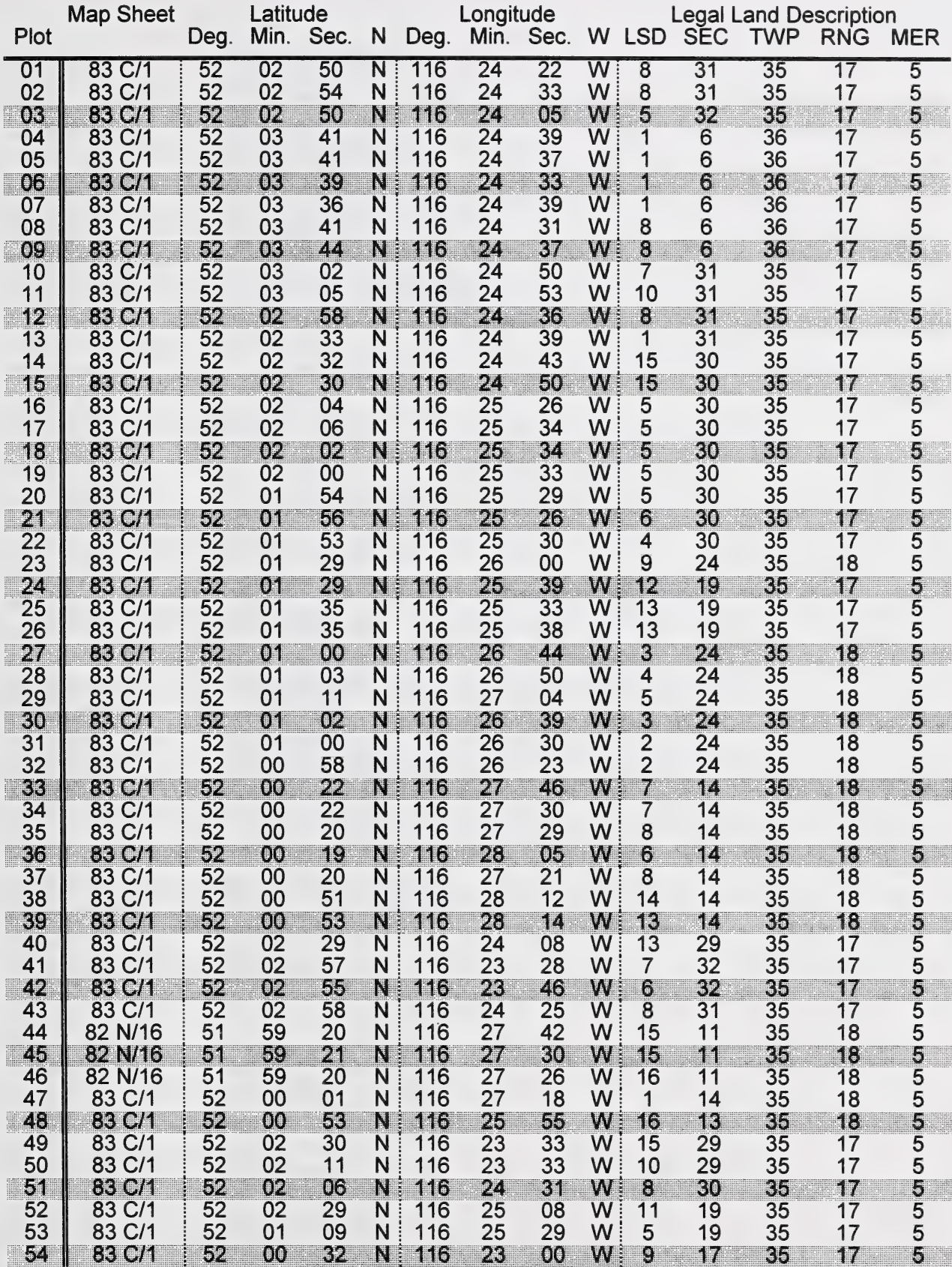




\section{APPENDIX 5}

Complete plant species list from detailed plot descriptions

\begin{tabular}{|c|c|}
\hline ACHIMIL & Achillea millefolium \\
\hline AGOSGLA & Agoseris glauca \\
\hline AGRODAS & Agropyron dasystachyum \\
\hline AGROSMI & Agropyron smithii \\
\hline AGROSPI & Agropyron spicatum \\
\hline AGROTRA & Agropyron trachycaulum \\
\hline AGROVIO & Agropyron violaceum \\
\hline ALLICER & Allium cernuum \\
\hline AMBLVAR & Amblystegium varium \\
\hline ANDRCHA & Androsace chamaejasme \\
\hline ANDRSEP & Androsace septentrionalis \\
\hline ANEMMUL & Anemone multifida \\
\hline ANEMPAR & Anemone parviflora \\
\hline ANTEPAR & Antennaria parvifolia \\
\hline ANTEPUL & Antennaria pulcherrima \\
\hline ANTEROS & Antennaria rosea \\
\hline ARABHOL & Arabis holboellii \\
\hline ARCTRUB & Arctostaphylos rubra \\
\hline ARCTUVA & Arctostaphylos uva-ursi \\
\hline ARTECAM & Artemisia campestris \\
\hline ARTEFRI & Artemisia frigida \\
\hline ASTEALP & Aster alpinus \\
\hline ASTECIL & Aster ciliolatus \\
\hline ASTECON & Aster conspicuus \\
\hline ASTEERI & Aster ericoides \\
\hline ASTELAE & Aster laevis \\
\hline ASTESIB & Aster sibiricus \\
\hline ASTRPEC & Astragalus pectinatus \\
\hline ASTRSPP & Astragalus spp. \\
\hline ASTRSTR & Astragalus striatus \\
\hline BETUGLA & Betula glandulosa \\
\hline BRACALB & Brachythecium albicans \\
\hline BRACGRO & Brachythecium groenlandicum \\
\hline BROMCIL & Bromus ciliatus \\
\hline BROMINE & Bromus inermis \\
\hline CALAMON & Calamagrostis montanensis \\
\hline CALASTR & Calamagrostis stricta \\
\hline CAMPHIS & Campylium hispidulum \\
\hline CAMPROT & Campanula rotundifolia \\
\hline CAMPSTE & Campylium stellatum \\
\hline CAREAQU & Carex aquatilis \\
\hline CAREAUR & Carex aurea \\
\hline CARECON & Carex concinna \\
\hline CAREDEW & Carex deweyana \\
\hline CAREFRA & Carex franklinii \\
\hline CAREGYN & Carex gynocrates \\
\hline CAREMIC & Carex microglochin \\
\hline CARESAX & Carex saxatilis \\
\hline CARESCI & Carex scirpoidea \\
\hline CARESCO & Carex scoparia \\
\hline CARESTE & Carex stenophylla \\
\hline CASTMIN & Castilleja miniata \\
\hline CATALAC & Catapyrenium lachneum \\
\hline
\end{tabular}





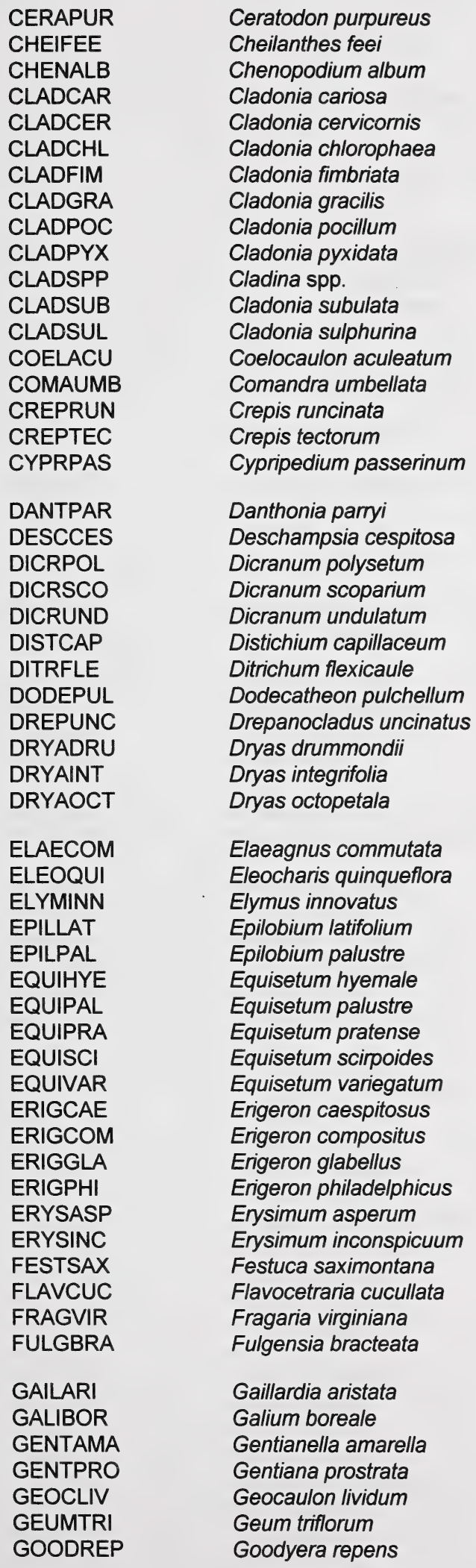




\begin{tabular}{|c|c|}
\hline $\begin{array}{l}\text { HABEHYP } \\
\text { HABEOBT } \\
\text { HABEVIR } \\
\text { HAPLLAN } \\
\text { HAPLLYA } \\
\text { HAPLUNI } \\
\text { HEDYALP } \\
\text { HEDYBOR } \\
\text { HETEVIL } \\
\text { HIERCYN } \\
\text { HYLOSPL } \\
\text { HYPNCUP } \\
\text { HYPNREV } \\
\text { HYPOAUS } \\
\text { HYPOPHY }\end{array}$ & $\begin{array}{l}\text { Habenaria hyperborea } \\
\text { Habenaria obtusata } \\
\text { Habenaria viridis } \\
\text { Haplopappus lanceolatus } \\
\text { Haplopappus Iyallii } \\
\text { Haplopappus uniflorus } \\
\text { Hedysarum alpinum } \\
\text { Hedysarum boreale } \\
\text { Heterotheca villosa } \\
\text { Hieracium cynoglossoides } \\
\text { Hylocomium splendens } \\
\text { Hypnum cupressiforme } \\
\text { Hypnum revolutum } \\
\text { Hypogymnia austerodes } \\
\text { Hypogymnia physodes }\end{array}$ \\
\hline ISOPELE & Isopterygium elegans \\
\hline $\begin{array}{l}\text { JUNCALP } \\
\text { JUNCBAL } \\
\text { JUNICOM } \\
\text { JUNIHOR }\end{array}$ & $\begin{array}{l}\text { Juncus alpinoarticulatus } \\
\text { Juncus balticus } \\
\text { Juniperus communis } \\
\text { Juniperus horizontalis }\end{array}$ \\
\hline $\begin{array}{l}\text { KOBRSIM } \\
\text { KOELMAC }\end{array}$ & $\begin{array}{l}\text { Kobresia simpliciuscula } \\
\text { Koeleria macrantha }\end{array}$ \\
\hline $\begin{array}{l}\text { LESQALP } \\
\text { LILIPHI } \\
\text { LINNBOR } \\
\text { LINULEW }\end{array}$ & $\begin{array}{l}\text { Lesquerella alpina } \\
\text { Lilium philadelphicum } \\
\text { Linnaea borealis } \\
\text { Linum lewisii }\end{array}$ \\
\hline $\begin{array}{l}\text { MEESULI } \\
\text { MUHLRIC }\end{array}$ & $\begin{array}{l}\text { Meesia uliginosa } \\
\text { Muhlenbergia richardsonis }\end{array}$ \\
\hline $\begin{array}{l}\text { ORTHLUT } \\
\text { ORTHSEC } \\
\text { ORTHSPP } \\
\text { OXYTMON } \\
\text { OXYTSER } \\
\text { OXYTSPL }\end{array}$ & $\begin{array}{l}\text { Orthocarpus luteus } \\
\text { Orthilia secunda } \\
\text { Orthotrichum spp. } \\
\text { Oxytropis monticola } \\
\text { Oxytropis sericea } \\
\text { Oxytropis splendens }\end{array}$ \\
\hline $\begin{array}{l}\text { PARNPAL } \\
\text { PEDIGRO } \\
\text { PELTAPH } \\
\text { PELTCAN } \\
\text { PELTELI } \\
\text { PELTNEC } \\
\text { PELTNEO } \\
\text { PELTPRA } \\
\text { PELTRUF } \\
\text { PHYSMUS } \\
\text { PICEENG } \\
\text { PICEGLA } \\
\text { PINGVUL } \\
\text { PINUCON } \\
\text { PINUFLE } \\
\text { PLANMAJ } \\
\text { PLEUSCH } \\
\text { POAAPAL } \\
\text { POAAPRA } \\
\text { POHLNUT }\end{array}$ & $\begin{array}{l}\text { Parnassia palustris } \\
\text { Pedicularis groenlandica } \\
\text { Peltigera aphthosa } \\
\text { Peltigera canina } \\
\text { Peltigera elisabethae } \\
\text { Peltigera neckeri } \\
\text { Peltigera neopolydactyla } \\
\text { Peltigera praetextata } \\
\text { Peltigera rufescens } \\
\text { Physconia muscigena } \\
\text { Picea engelmannii } \\
\text { Picea glauca } \\
\text { Pinguicula vulgaris } \\
\text { Pinus contorta } \\
\text { Pinus flexilis } \\
\text { Plantago major } \\
\text { Pleurozium schreberi } \\
\text { Poa palustris } \\
\text { Poa pratensis } \\
\text { Pohlia nutans }\end{array}$ \\
\hline
\end{tabular}




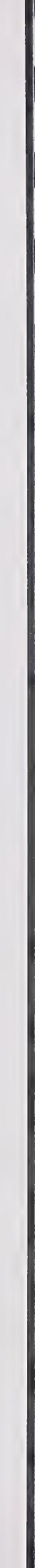


POHLSPP

POPUBAL

POPUTRE

POTECON

POTEFRU

POTEGRA

PSORCER

PSORDEC

PSORRUB

PTILCRI

PYROASA

ROSAACI

RUBUARC

SALIATH

SALIBRA

SALICAN

SALIGLA

SALIMYR

SALIVES

SAXIAIZ

SELADEN

SENECAN

SHEPCAN

SISYMON

SMILSTE

SOLICAN

SOLIMUL

SONCOLE

SPIRBET

SQUALEN

STIPCOM

TARAOFF

THALVEN

THUIABI

TOFIGLU

TORTFRA

TORTRUR

TRIGMAR

TRIGPAL

VIOLADU

VIOLNEP

VIOLREN

XANTCHL

XANTWYO

ZIGAELE

ZIZIAPT
Pohlia spp.

Populus balsamifera

Populus tremuloides

Potentilla concinna

Potentilla fruticosa

Potentilla gracilis

Psora cerebriformis

Psora decipiens

Psora rubiformis

Ptilium crista-castrensis

Pyrola asarifolia

Rosa acicularis

Rubus arcticus

Salix athabascensis

Salix brachycarpa

Salix candida

Salix glauca

Salix myrtillifolia

Salix vestita

Saxifraga aizoides

Selaginella densa

Senecio canus

Shepherdia canadensis

Sisyrinchium montanum

Smilacina stellata

Solidago canadensis

Solidago multiradiata

Sonchus oleraceus

Spiraea betulifolia

Squamarina lentigera

Stipa comata

Taraxacum officinale

Thalictrum venulosum

Thuidium abietinum

Tofieldia glutinosa

Tortella fragilis

Tortula ruralis

Triglochin maritima

Triglochin palustris

Viola adunca

Viola nephrophylla

Viola renifolia

Xanthoparmelia chlorochroa

Xanthoparmelia wyomingica

Zigadenus elegans

Zizia aptera 


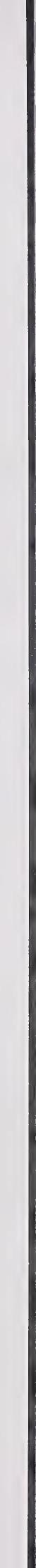




\section{APPENDIX 6}

Habitat and diagnostic features of Brachythecium albicans (S2?)
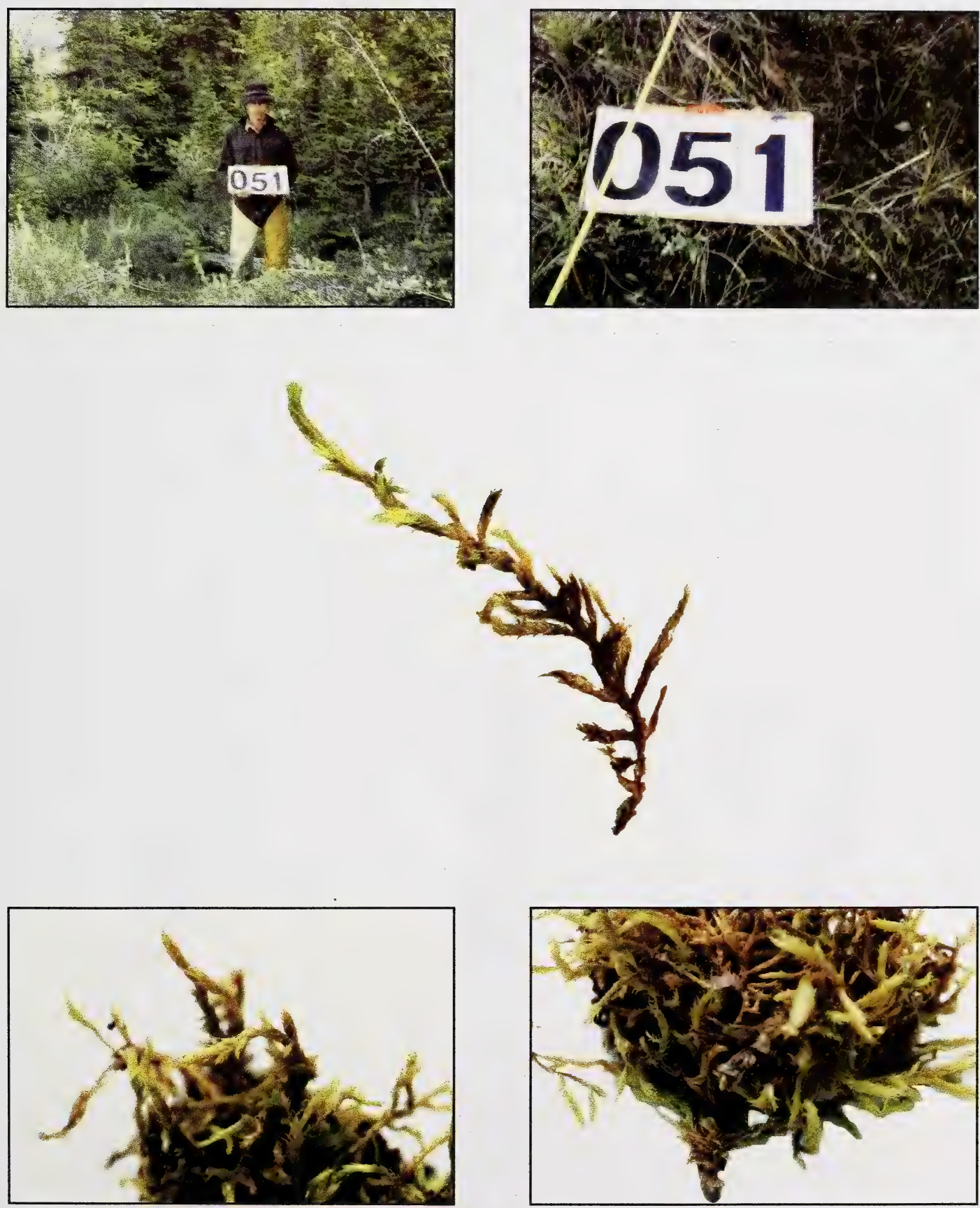


\section{APPENDIX 7}

Habitat and diagnostic features of Carex franklinii (S2)
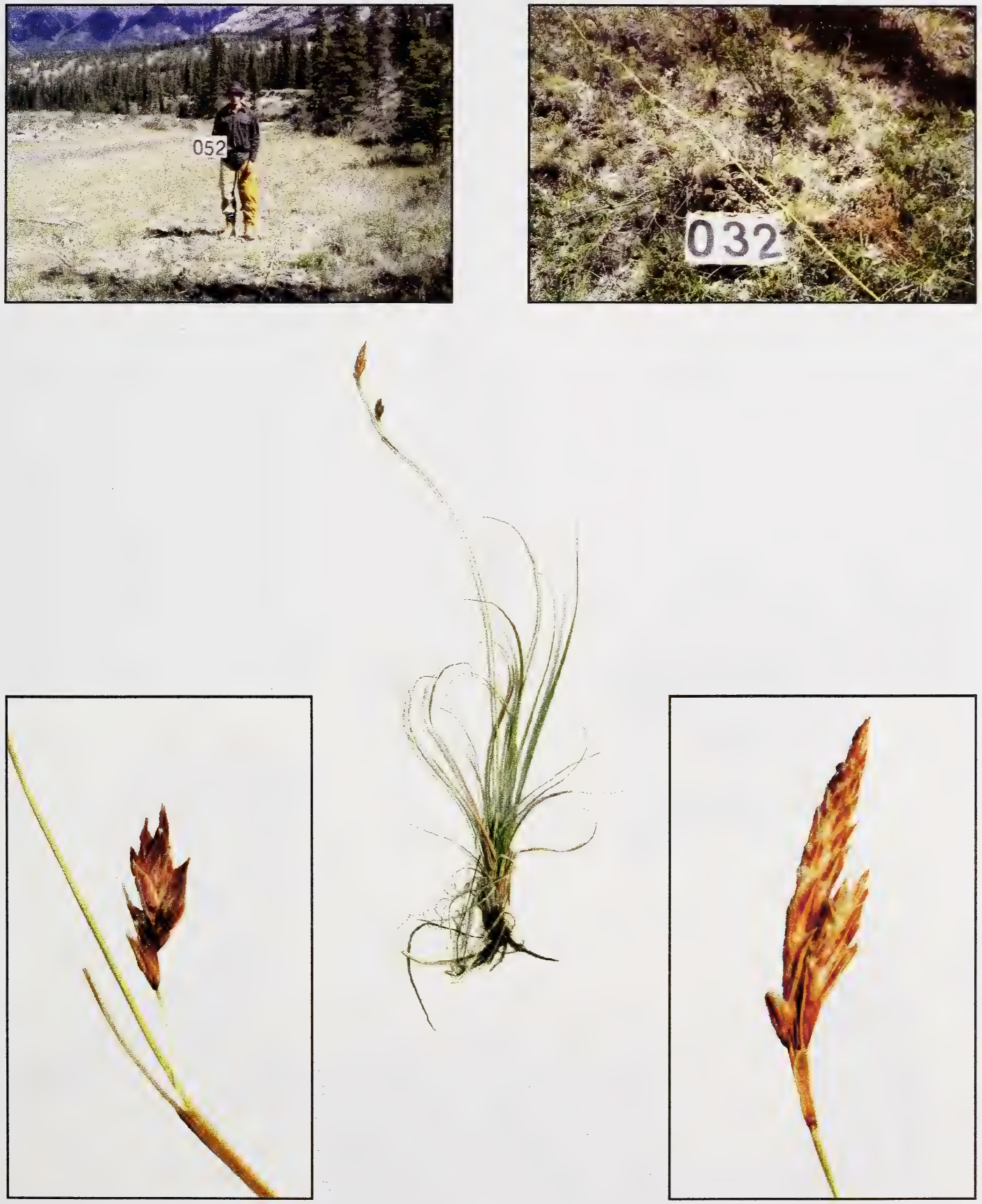



\section{APPENDIX 8}

Habitat and diagnostic features of Erysimum asperum (S3)
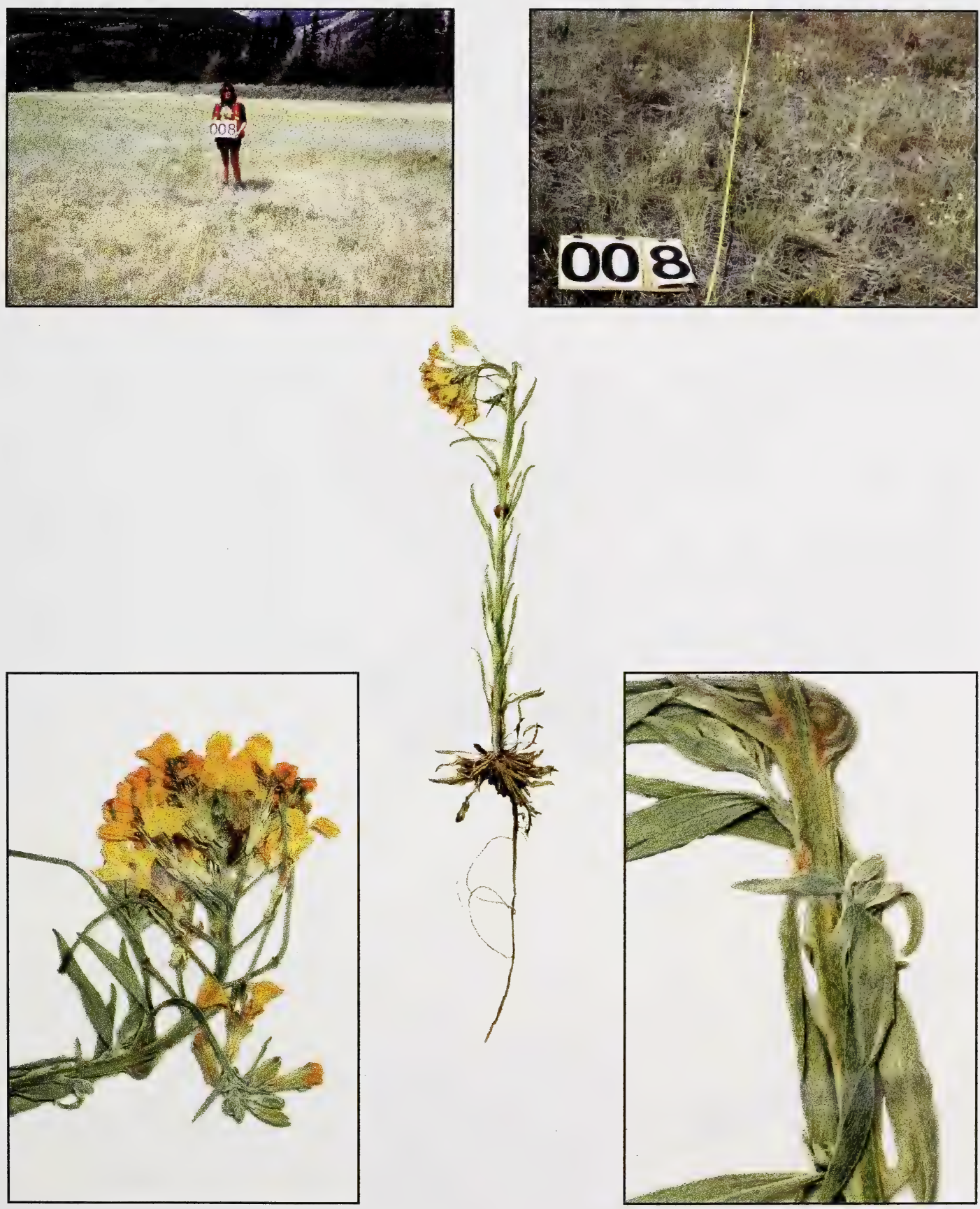


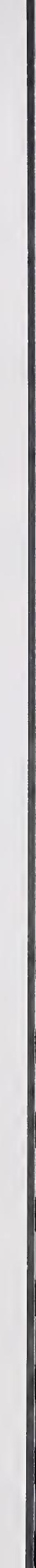




\section{APPENDIX 9}

Habitat and diagnostic features of Haplopappus lyallii (S2)
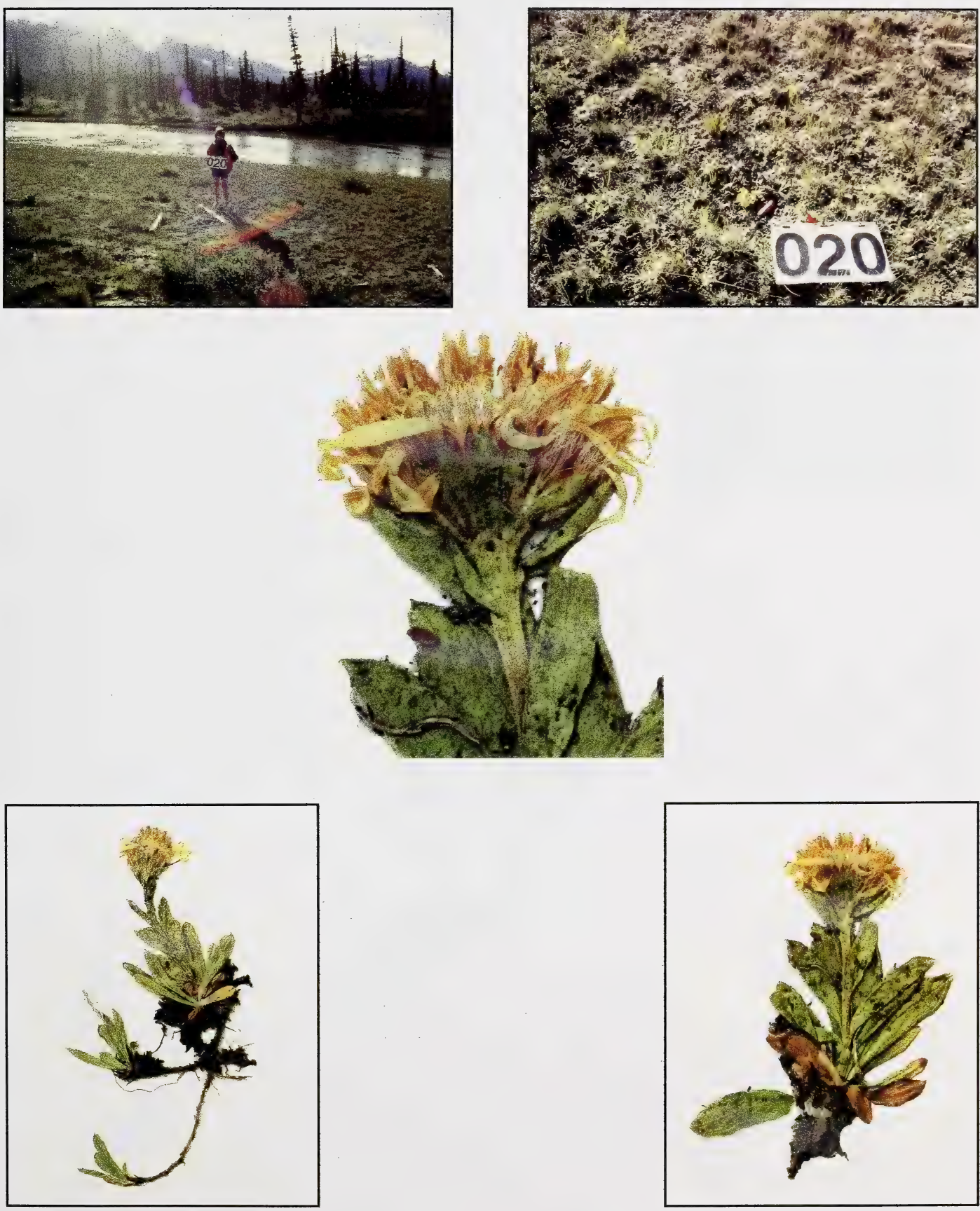


\section{APPENDIX 10}

Habitat and diagnostic features of Haplopappus uniflorus (S3)
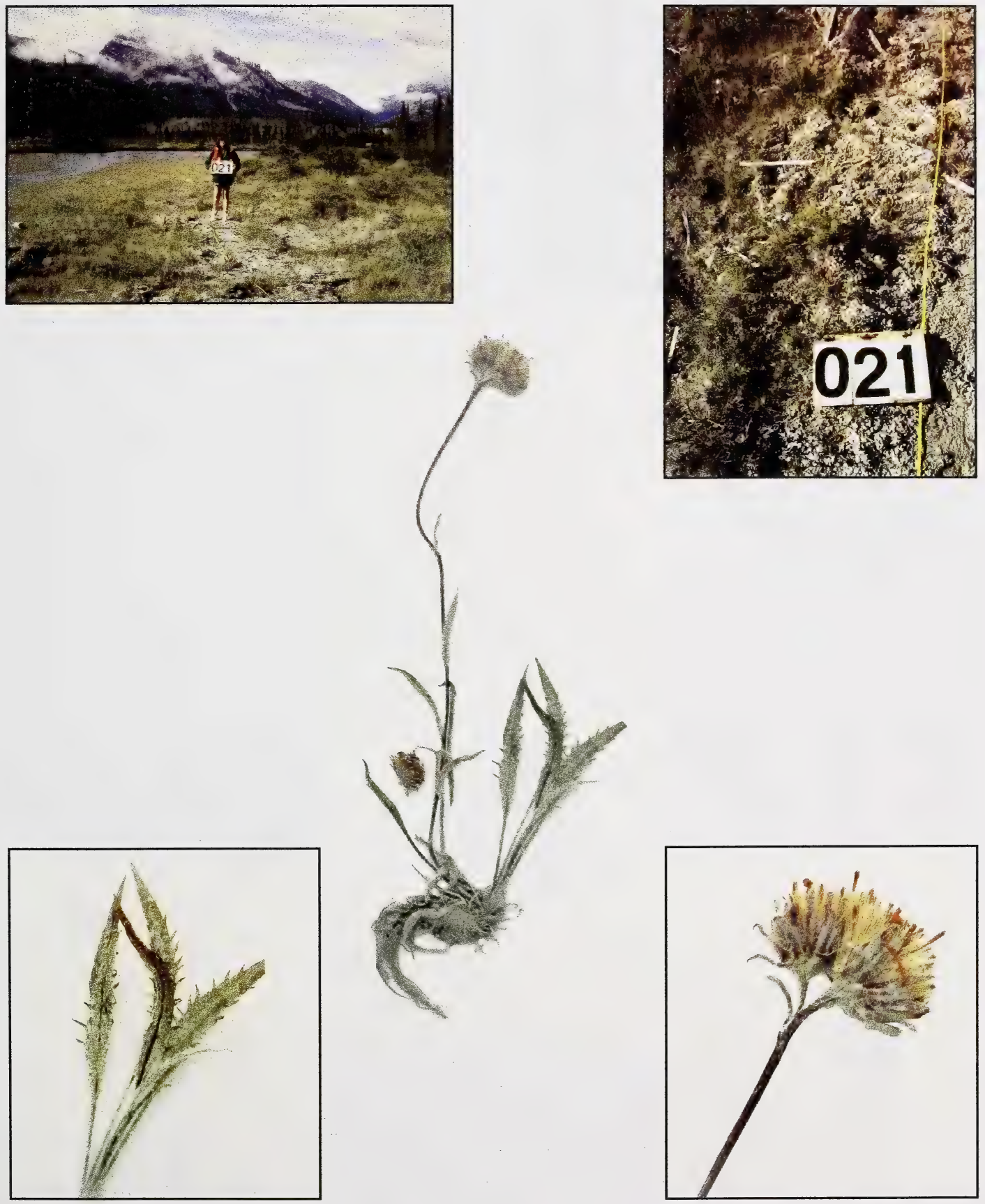


\section{APPENDIX 11}

Habitat and diagnostic features of Hieracium cynoglossoides (S2)
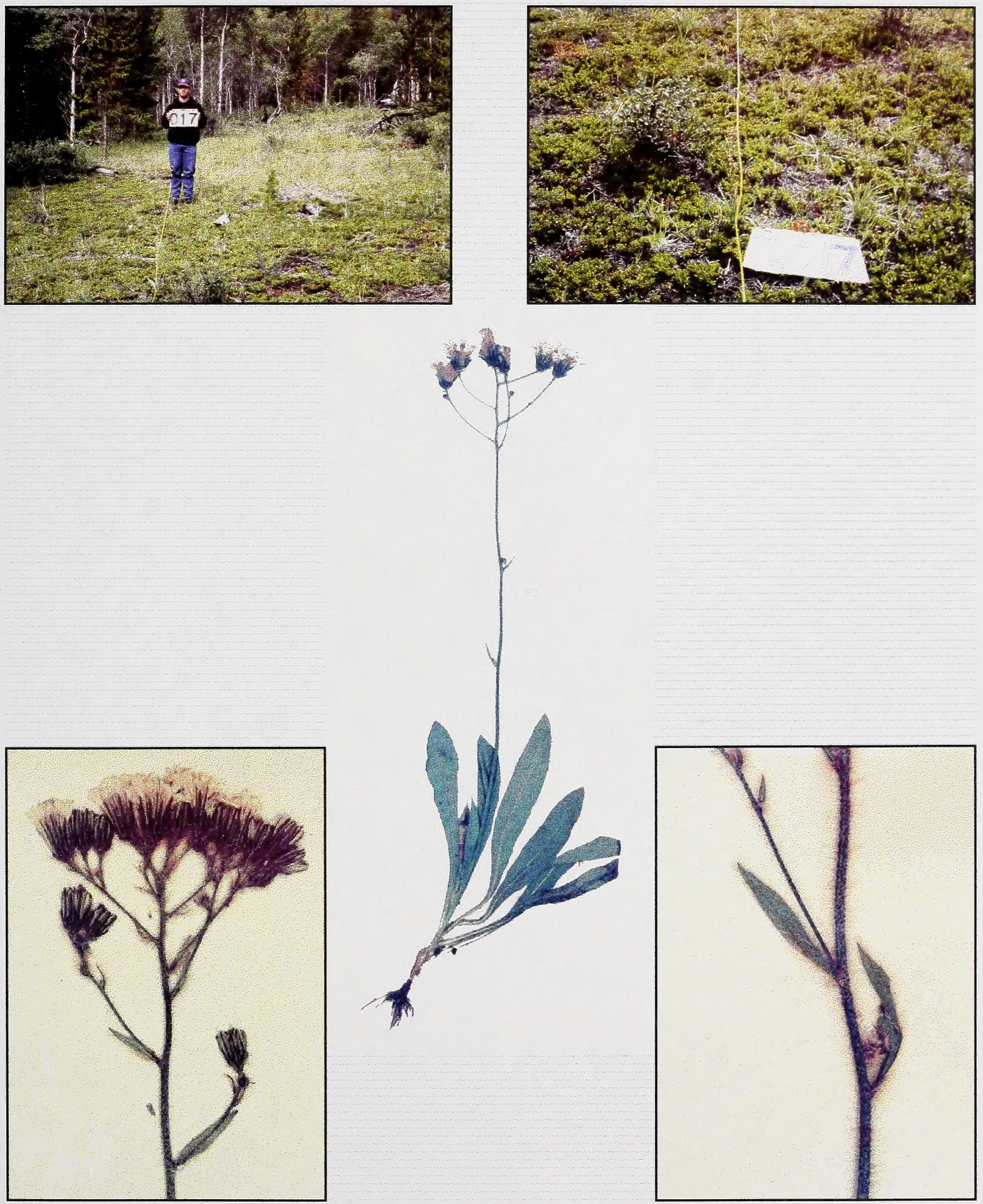

